\title{
Can Post-Vaccine 'Vaxication' Rejuvenate Global Tourism? Nexus between COVID-19 Branded Destination Safety, Travel Shaming, Incentives and the Rise of Vaxication Travel
}

\author{
Umer Zaman ${ }^{1, *(\mathbb{D}}$, Murat Aktan ${ }^{2} \mathbb{D}$, Mahwish Anjam ${ }^{3}$, Jerome Agrusa ${ }^{4}$, Muddasar Ghani Khwaja ${ }^{5}(\mathbb{C}$ \\ and Pablo Farías 6 \\ 1 Endicott College of International Studies (ECIS), Woosong University, Daejeon 34606, Korea \\ 2 Faculty of Economics and Administrative Sciences, Muğla Sitki Kocman University, Muğla 88000, Turkey; \\ murataktan@mu.edu.tr \\ 3 College of Business Studies, Al-Ghurair University, Dubai 37374, United Arab Emirates; m.anjum@agu.ac.ae \\ 4 School of Travel Industry Management, Shidler College of Business, University of Hawaii at Manoa, \\ Honolulu, HI 96822, USA; jagrusa@hawaii.edu \\ 5 Departamento Académico de Ciencias de la Gestión-Sección Gestión, Pontificia Universidad Católica del \\ Perú, San Miguel, Lima 15088, Peru; khawajamuddasar@gmail.com \\ 6 Departamento de Administración, Facultad de Economía y Negocios, Universidad de Chile, \\ Santiago 8330015, Chile; pfarias@fen.uchile.cl \\ * Correspondence: umerzaman@endicott.ac.kr
}

Citation: Zaman, U.; Aktan, M.; Anjam, M.; Agrusa, J.; Khwaja, M.G.; Farías, P. Can Post-Vaccine

'Vaxication' Rejuvenate Global Tourism? Nexus between COVID-19 Branded Destination Safety, Travel Shaming, Incentives and the Rise of Vaxication Travel. Sustainability 2021, 13, 14043. https://doi.org/10.3390/ su132414043

Academic Editors: Yinghua Huang, Zach Hallab and Lujun Su

Received: 14 November 2021 Accepted: 16 December 2021 Published: 20 December 2021

Publisher's Note: MDPI stays neutral with regard to jurisdictional claims in published maps and institutional affiliations.

Copyright: (c) 2021 by the authors. Licensee MDPI, Basel, Switzerland. This article is an open access article distributed under the terms and conditions of the Creative Commons Attribution (CC BY) license (https:// creativecommons.org/licenses/by/ $4.0 /)$.

\begin{abstract}
Vaxication (i.e., post-vaccination travel) and branding destinations for COVID-19 safety have emerged as the cornerstones to fully rebound global tourism. Numerous destination brands are now stimulating tourism demand through realigned travel incentives specifically for fully vaccinated travelers. However, there is growing fear and incidents of travel shaming across destinations, especially due to the recent outbreaks of the highly contagious COVID-19 'delta and omicron' variants. Addressing this critical research gap, the present study makes pioneering efforts to empirically examine the effects of COVID-19 branded destination safety (CBDS) on vaxication intentions, under the moderating influence of travel shaming and travel incentives. Drawing on study data from 560 fully-vaccinated residents from Hawaii, United States and structural equation modeling (SEM) with Mplus, the evidence suggests that the positive impact of CBDS on vaxication intention can be further strengthened by travel incentives, or weakened when travel shaming picks up more momentum. Besides the validation of newly developed scales, the study offers strategic insights based on dominant theories (e.g., theory of planned behavior and protection motivation theory) to interpret the changing tourism demand, and to transform the emerging challenges into opportunities through and beyond the pandemic.
\end{abstract}

Keywords: vaxication; COVID-19 branded destination safety; travel shaming; travel incentives; global sustainable tourism; theory of planned behavior; protection motivation theory

\section{Introduction}

A sense of travel optimism continues to rise with the increasing scale of global immunization against COVID-19 and the cautious easing of the pandemic-induced travel restrictions (e.g., lockdowns, quarantines, and social distancing, etc.) [1,2]. However, the devastating effects of the prolonged pandemic on the global tourism industry (e.g., 84 percent overall decline in international tourism, a speculated loss of USD \$4 trillion to the tourism-reliant global economy, and 62 million lost jobs, etc.) have caused a major paradigm shift for destination branding and destination safety, respectively [3-5]. Restarting tourism operations now requires destination reassurance for COVID-19 safety in order to attract fully-vaccinated travelers seeking reliable and safer options to travel $[2,6,7]$. In order to reopen safely, tourism destinations have started to rebrand themselves for the 
highest degree of COVID-19 safety (e.g., offering resort bubbles, robot-disinfected guestrooms, and hand sanitizing stations, etc.) [3]. As fully-vaccinated travelers (e.g., 59\% of nationals in the United States) may be more eager to travel again, CBDS reinforces their travel decisions, despite the emerging gaps between the least and the most safe destinations for tourism during the pandemic $[3,7,8]$. Moreover, CBDS balances the safety and branding needs of destinations that strive to reopen themselves for international visitors by restoring confidence, boosting re-bookings, and avoiding frequent cancellations [9,10]. Hence, CBDS has emerged as the economic lifeblood for global tourism hotspots (e.g., Hawaii, Turkey, Italy, and Spain, etc.), especially for destinations that are highly dependent on international tourism. Leveraging CBDS can now be a turning point for destinations to survive and remain strong during and after the pandemic [3,11,12].

Besides the incredible economic damage, the COVID-19 pandemic has also triggered significant behavioral change across global tourism destinations $[4,13]$. During the pandemic, a new behavioral variant of travel shaming (i.e., shaming others for their travel during the pandemic) emerged from its pre-pandemic conditions (i.e., shaming others for less travel) [4]. Travel shaming incidents have recently escalated, especially due to the shocking imbalance in vaccination rates across countries, the growing influx of travelers to and from amber (i.e., self-isolation), red (i.e., mandatory hotel quarantine) and green (i.e., quarantine-free) travel lists, and the high transmission risk of the more contagious COVID19 'delta and omicron' variants $[4,8,14,15]$. Hence, even fully-vaccinated travelers can still experience travel shaming, especially when they choose a tourism destination with higher infection rates, lower vaccination rates, and/or red-list status (e.g., Malawi, South Africa, and Zimbabwe, etc.) $[4,16,17]$. Despite growing optimism, global tourism is still not expected to return to its pre-pandemic level before 2023 [2]. As COVID-19 restrictions slowly drift away, tourism destinations are aggressively competing for tourist dollars. Tourism hotspots around the world have reconfigured their financial incentives (e.g., offering subsidized or free airline tickets, redeemable vouchers, COVID-19 payouts and a free night's stay for each night paid by visitors, etc.) to kickstart tourism and lure fully-vaccinated travelers searching for a long-haul vacation $[18,19]$. Several tourism destinations (e.g., Cyprus, Portugal, Spain, and Malta, etc.) have also recently exempted fully-vaccinated international travelers from mandatory quarantines and negative coronavirus tests [20]. Hence, the pandemic has tempted tourism destinations to attract fully-vaccinated travelers by branding themselves for COVID-19 safety and offering encouraging travel incentives, including exclusive benefits, privileges, aggressive discounts, and diverse promotions [1,3,18,21,22].

Strategic focus on COVID-19 branded destination safety and understanding the intentions of fully-vaccinated travelers are critical for global tourism to recover from its current state of market paralysis, and to reopen the entire world back to tourism [1,9,12]. Hence, the acceleration of vaxication through CBDS can drive promising tourism growth and destress the global tourism industry until or after the pandemic disappears $[3,16]$. Despite rising scholarly attempts and extensive research focused on safeguarding tourism during and after the pandemic [2], the vaxication intention of fully-vaccinated travelers remains largely under-explored $[13,23]$. Importantly, tourism literature presently lacks empirical evidence on how CBDS can significantly boost vaxication intention $[3,6,13,16]$. As the tourism industry continues its global struggle to escape the pandemic, CBDS and redesigned travel incentives can significantly help destinations to recover faster and pull back international tourism $[4,12,21,22]$. However, due to the growing behavioral shift (i.e., travel shaming) induced by the highly-contagious COVID-19 'delta and omicron' variants, largely non-vaccinated vulnerable populations and uneven tourism growth across destinations may still continue to dampen the hopes for vaxication $[2,4,16,24]$. In order to address these critical research gaps and identify sustainable solutions for global tourism [1,9,12], the present study makes pioneering efforts to highlight dominant theories (e.g., theory of planned behavior and protection motivation theory) to explore the potential effects of CBDS on vaxication intention (involving fully-vaccinated residents in Hawaii), especially under the moderating influence of travel shaming and travel incentives $[4,18,19]$. 


\section{Theoretical Background}

\subsection{COVID-19 Branded Destination Safety}

'Brand' is a term used to identify or differentiate a product or service by shaping consumer behavior, aiming at creating loyalty, premium, and market appeal, etc. [25]. According to the hierarchy effects model, a brand helps to establish product/service recognition, awareness, image, and memory in the minds of the consumers [26]. Likewise, the concept of branding has evidently been advocated to be equally significant for people, places, and destinations of tourism [27,28]. Attributes like attractions, tourism infrastructure, accessibility, and amenities are some of the key factors characterizing tourism destinations [29]. Tourism destinations are considered to be a form of leisure consumption, falling into the category of the consumer service industry, where the importance of branding has overwhelmingly been recognized [28,30-34]. Ritchie and Ritchie [35] defined destination branding as

... a name, symbol, logo, word, mark or other graphic that both identifies and differentiates the destination. Furthermore, it conveys the promise of a memorable travel experience that is uniquely associated with the destination, and it also serves to consolidate and reinforce the recollection of pleasurable memories of the destination experience. (p. 103).

Destination branding in tourism literature has been justified as a source of the stimulation of customer satisfaction, attaining a competitive advantage through the creation of differentiation, and establishing a unique association with the destination [36-38], thereafter leading to customer loyalty behavioral intentions and repeated tourism [39,40]. Likewise, destination image has also been a popular subject for researchers and marketers [29]. Early studies in tourism validated the impact of positive destination brand image as a strong factor, significantly impacting the customer's visiting intentions [41]. Therefore, tourism destinations are being planned and marketed for a spirited image, unique perception, and associative knowledge to be utilized by the customer to identify and evaluate tourism places [31,42]. In this context, the theory of planned behavior (TPB) has widely been referred to in the justification of the travelers' behavioral intentions towards their destination of choice [43-45]. The TPB suggests that the consumer will choose to behave in a particular way if he perceives that his behavior will result in the desired outcome, while attitudes, social norms and perceived behavioral control are the key contributors of such behavior [46-48]. The application of the TPB validates the supposition that the tourists' positive/negative attitude towards the destination, social approval of the choice of destination, and perceived control over time and resources, etc., play a significant role in the choice of a tourist destination [43].

The outbreak of the COVID-19 pandemic, with more than 174 million confirmed cases and more than 3.4 million deaths worldwide, has had a critical impact on economies and businesses. Strict WHO regulations, country lockdowns, social distancing practices, quarantine, mobility bans, and travel restrictions have adversely impacted many industries and businesses, with tourism and hospitality being on the hardest-hit list. Being vulnerable to various political, environmental, societal, and economic factors, tourism has overall been a volatile industry [49]; however, its susceptibility to the recent pandemic is unmatched. It has been declared as the worst tourism decline of history, with a tourist mobility decrease of $78 \%$ and tourism-related job cuts of approximately 120 million [50]. Amidst the COVID-19 pandemic, destinations and tourism operators are battling to ensure the safety and protection of customers whilst maintaining their positive brand image and profitability. This momentum has led to the rise of a new marketing strategy, namely COVID-19 branded destination safety, which is the combination of destination branding and destination safety concepts. Furthermore, destinations' safety and security perceptions constitute the most influential element of tourist's choice, as well as destination brand image, which could lower or augment travel intentions towards the destination [51,52]. In light of this, COVID-19 branded destination safety refers to the branding of a tourism destination as a safe haven 
from the risks of COVID-19 [53]. In this respect, some destinations have started to host smaller tourist groups along with the organization of private tours with outdoor activities. Furthermore, COVID-19 branded destination safety implications include social distancing, contact-free services, gathering restrictions, hygiene and cleaning assurances, the accessibility of disinfectants and sanitizers, and the availability of health-check equipment, etc. [18]. Hence, COVID-19 branded destination safety is recognized as a critical element that is instrumental in boosting tourist confidence and impacting the travelers' destination visit intentions and behavior [12,51-54].

\subsection{Travel Incentives}

In today's competitive market, targeting and achieving customer loyalty has been more difficult than ever before. Managing consumer behavior related to tourism and destination management requires a deeper understanding of consumers' travel intentions, attitudes, and behaviors flowing from holidays, vacation trips, and leisure activities. The use of travel incentives has been emphasized to be a valuable strategy in establishing favorable travel behavioral intentions and enhancing customer loyalty in the tourism sector $[55,56]$. Travel incentives refer to the promotions, discounts, enticements, offers, rebates, and concessions, etc., which are intended to motivate the customer. The significance of introducing incentives as a business-boosting strategy has largely been recognized in the literature, and has been advocated as an effective way of attracting travelers [57-59]. Zhu et al. [56] concluded that incorporating various incentives, including cost, discounts, and promotions, etc., is a critical demand management strategy intending to shape travelers behavior intentions. The literature suggests that the decision on the choice of travel destination is influenced by the travelers' motivation, which is driven out by two factors called 'Push' and 'Pull' [60]. The push and pull framework indicates that these are equally important: the socio-phycological, external factors that motivate a tourist to travel are known as push factors, e.g., promotions and incentives, whereas the attributes and features of the destination used to attract a traveler are termed the pull factors $[59,60]$. Therefore, incentives are carefully designed to cater to the needs of the customer in order to stimulate their intentions to travel by targeting various psychological desires [55].

Furthermore, travel incentives and promotions are also acknowledged to be a useful revival approach worthy of consideration by governments and companies for boosting the country and tourism image by incorporating strategies including promotion communication and offering subsidized prices for the products and services related to tourism [61,62]. Greece, in an effort to revive itself from the reputation damage caused by the political unrest in the country, offered various price cuts in airfare, ferries, and hotels; Bali in 2002 and Thailand in 2014 were also seen to employ similar approaches of price reduction and promotional discounts intended to revitalize tourism and destination image [62]. Moreover, there is ample literature to support the employment of travel incentives as an employee motivation strategy in the organizations, where destination visits are used as a performance incentive offered to high-performing employees [63,64]; however, employee motivation-based travel incentives are not the focus of this study.

Similarly, as a COVID-19 pandemic retrieval strategy, in an attempt to save battered tourism industries, various countries are offering flight discounts, promotional vouchers for local attractions, discounted-to-free access to tourist sites, and even government-sponsored medical expenses for during-the-visit possible COVID-19 infection encounters [65]. Some of the travel incentives being offered by various branded destinations and countries include (but are not limited to): Mexico offering free hotels, rented cars, and discounted tourist destinations; Italy, with up to a $50 \%$ promotion in airfare and hotel accommodation; Cyprus paying all travel expenses including food and accommodation for anyone who catches COVID-19 during the visit; Uzbekistan announcing \$3000 for traveler's catching coronavirus during the visit; and Emirates airline's year-long travel incentives for students by offering discounts, visa promotions and a free change of tickets, etc. [21,22]. It is thus evident from the literature that, as a post-pandemic revival strategy, the tourism 
and destination markers are reassessing their offerings and value propositions, and are incorporating various incentives and promotions as an effort to boost consumers' intentions to travel.

\subsection{Travel Shaming}

The outbreak of COVID-19 brought a major shift in lifestyles, patterns, and behaviors. Travel and mobility were some of the few first things which were linked to the spread of the virus, and consequently, as a preventive measure, lockdowns and travel bans were imposed immediately. Although, with time, the travel restrictions were eased out, there are still some apprehensions about leaving home, social mobility, and traveling [21]. There are health concerns related to catching and spreading the virus from one place to another; as a result, the concept of 'travel shaming' has recently evolved [17]. Travel shaming is traditionally used to embarrass people subtly and overtly by making them feel guilty about not being able to travel by showing videos and pictures of the visited places. However, the recent pandemic has altered the definition and the meaning of travel shaming altogether [66]. It has now been defined as a way of criticizing people who opt to travel during the COVID-19 pandemic. People are being judged for posting their travel details, videos, and pictures for being insensitive towards the adversities of the pandemic [14,15]. The new era of travel shaming is growing stronger with every passing day with the inclusion of additional shaming concepts, including mask shaming (for not being able to wear the mask), social distance shaming (for not being able to maintain a reasonable distance), and virus shaming (for catching the virus itself) [14]. Although the restrictions for hotels, airlines, travel and hospitality are being eased out, and although tourism and hospitality businesses have slowly started to venture out all over again, the travel-shaming attitude towards vacations and even business travel is loud and bold, making it a concerning issue for tourism and travel managers and marketers [17].

In the current pandemic, travel-shaming behavior can thus be justified in the light of the protection motivation theory (PMT). Rogers [67] suggested that the preventive behavior of an individual is the outcome of the motivation of an individual to protect himself from harm or threats. It is further proposed that fear-provoking communication can substantially influence behaviors. Further studies on PMT validated the theory that the consistent increase in the fear was arousing communication results in proposed adaptive behavior acceptance [68]. PMT has been studied extensively concerning travel behaviors and intentions [4,69-71]. Risk perception is the center of attention of various researchers working on PMT and travel intentions. Perceived severity and perceived vulnerability are reported to be two critical factors in the shaping of the behaviors and attitudes towards travel [72]. Amid the COVID-19 pandemic, the rapid spread of cases, high death rates, preventive measures put in place by the countries and governments, and precautionary advisories by the WHO built the perception of the risk severity. Whereas the higher chances of virus transfer resulting from usual human contact reinforced the risk. As proposed by Rogers [67], the threat appraisal of COVID-19 results in a coping mechanism of mobility restrictions. Mobility is perceived as the main source of the spread of COVID-19, and hence is associated with illness and health risk [24]. Therefore, travel during the pandemic refutes the proposed adoptive behavior, thus leading to travel shaming intentions and behaviors.

\subsection{Vaxication Intention}

With the availability of various vaccines (e.g., Pfizer/BioNTech and Moderna) to curb the spread of COVID-19, social life is presumed to be resuming normalcy slowly and gradually. Social mobility, travel, and tourism are also predicted to be resuscitated once the larger population is assured of its immunity to COVID-19. Therefore, the COVID19 vaccination - being the assurance of immunity against the virus - is emerging as an immunity passport which is required for entry into various countries, movement from one place to another, air travel revival, and travel to the favorite destinations for vacations [73]. For global travel, COVID-19 vaccination has been considered as a social accord, at least, 
if not a legal requirement [74]. Celebrating post-lockdowns and post-vaccine, there has been a notable upsurge in the travel, tourism, and hospitality, and the term 'vaxication' has been introduced as a new addition to the literature, referring to travel plans for vaccinated people (as a combination of 'vaccination' (vax) and 'vacations'). The vaxication trend is gaining popularity, promising a needed boost in the travel and hospitality industry. It is anticipated that, as a future trend, the vaccination and vacation promotion packages will be used by marketers to promote vaxication [74]. The president of a Denver-based travel company reported a $25 \%$ increase in travel and vacation enquiries after the COVID-19 vaccination was rolled out in the USA, where the nature of such vaxications are trips to celebrate the attainment of immunity against the deadly virus and the resumption of mobility [75].

Although there has been no empirical research yet that has examined this new phenomenon of vaxication, comprehending various grounded theories related to health, risk and travel can facilitate an understanding of the tourists' vaxication intention. Theories related to health risk perceptions and beliefs are used as a mechanism to understand the health-related decision-making process. The Health Belief Model (HBM) has largely been validated in the literature for the establishment of a relationship between health-related behaviors and acquiring health services [76-79]. The HBM suggests that a person's belief about the severity of, exposure to, and vulnerability towards the illness, along with perceptions about the possible pros and cons of the health intervention (the vaccine), develop their health behaviors [79]. The HBM has also been studied for the prediction of the behavior regarding the acceptance and adoption of the COVID-19 vaccine [79,80], and is one of the co-predictors for tourism intentions [81]. Similarly, heath risk has also been validated by the Protection Motivation Theory (PTM), where the perceived threat appeal (COVID-19) and the coping mechanisms (vaccination) are advocated to be the substantial factors in the shaping of travel behaviors while choosing the travel destination $[67,71,82]$. Likewise, considering the health and safety concerns, the literature suggests an extension of the theory of planned behavior, emphasizing the incorporation of the impact of health and safety with the inclusion of the perceived knowledge of COVID-19 and psychological risk as prominent factors impacting the attitude, subjective norms, and behavioral intentions to travel to safe destinations $[52,83]$. The vaxication movement is still in a premature state because the pandemic has still not been called off; therefore, the impact and consequences of vaxication on the tourism and travel industry are yet to unfold. Despite gaining the spotlight in global tourism very recently, there has not been any empirical research on vaxication yet. Vaxication has emerged as a favorable trend, potentially capable of the revival of travel and tourism by assuring the necessary health and safety protocols, including the COVID-19 vaccine as a prime requirement for traveling to a favorite destination [73-75].

\subsection{Theoretical Framework and Research Hypotheses}

\subsubsection{CBDS and Vaxication Intention}

The COVID-19 pandemic has had an overreaching and profound impact, radically changing the way the travel and tourism industry operates [18]. Researchers have emphasized the need to investigate and discover ways for the travel and hospitality industry to recover from the adversities of this pandemic, and to identify the strategies for the post-COVID-19 sustainability of the tourism and hospitality industry [84]. In order to ensure the well-being of the people and to plan a sustainable resilience strategy for the revival of tourism, it is paramount to ensure the safety of the tourism destination. It is further evident that tourists' safety and security are surfacing as a critical determinant in uplifting tourist confidence and impacting the travelers' intention to visit $[12,51-54]$. Furthermore, the literature also advocates the safety factor to be a significant factor for ensuring competitiveness in the tourism industry [85]. Proposing a charter for the travel and hospitality industry, Chang, McAleer, and Ramos [84] stressed ensuring social distance regulations at the tourism destination, travel and entry rationing, controlling medical and health situations at the tourism destinations, and managing tourist hotels and accommoda- 
tions, etc., as post-pandemic ways forward towards sustained tourism industry. A study on post-pandemic travelers' behavior revealed a major shift in the marketing and promotional strategy of the tourism industry, with an increased focus on alternative methods of communicating and interacting with travelers [86].

The literature suggests a major shift in travelers' decision-making processes [2,87]. Referring to the theory of planned behaviour (TPB), prior studies suggest a significant link between a positive/negative attitude towards the destination, social approval of the choice of destination (social norms), perceived control over time and resources (perceived behavioral control), and the desire to visit/revisit a destination [43]. Moreover, the extended Theory of Planned Behaviour is relevant even further in justifying the vaxication intention. Post-COVID-19 mobility, perceived risk, safe global travel intentions, and safety behaviors are suggested to impact various dimensions of the TPB, and are thus advocated to be added to an extended TPB model [52]. Realizing the significance, countries and tourism operators have already started marketing destinations by highlighting the safety precautions, social distancing assurance, free hospitalizations, medical and illness insurance for COVID-19related illness, and financial support for catching coronavirus during the visit [21,22].

Amidst the pandemic, the tourism associated with the branded destination is anticipated to be translated in terms of the vaxication intention of the customers. Vaxication intention is principally based on the assurance of the safety precautions to curb the adverse effects of the virus (via vaccination), and to celebrate the successful revival of global tourism (in response to the adversities of COVID-19) by the post-vaccine intention to travel [75]. Despite being fully vaccinated and having decided about traveling, consumers will continue to live in a pandemic environment until the realization of a foreseeable future. Therefore, it is anticipated that as a psychological, social, and legal agreement, the vaxication will mainly be planned for those destinations that assure COVID-19 health and safety protocols and conform to the precautionary advisories of the WHO. Marketing and promoting safety as a key feature of destination branding has emerged as a significant factor to boost travelers' vaxication intentions [12,51-54]. Hence, the present study's first hypothesis was formulated as follows:

Hypothesis 1 (H1). CBDS has a positive effect on vaxication intention.

\subsubsection{Moderating Effects of Travel Incentives}

Promotional campaigns, incentives and discounts are acknowledged to be indicative of influencing purchase decisions and simulating sales in the short run [88,89]. Likewise, In the tourism and hospitality industry, attracting customers using incentives, discounts and promotions has also been validated as a valuable marketing strategy to ensure an increase in short-term sales $[61,89,90]$. Aiming at seeking effective ways to differentiate the services from others, the marketers plan and offer multiple incentives and promotions, including packages targeting hedonic and utilitarian value, and incentives based on value increase and value addition [91-94]. Suggestively boosting the brand and reinforcing the company's brand image, the 'value increase' refers to the incentives focusing on price reductions or incentives, which are designed to match the price and quality to enhance the perceived value, whereas the 'value adding' incentives refer to the offering of extra benefits (piggybacks or gifts, gaining points, freebies, etc.) which are complimentary to a standard package [94]. A study conducted on fifteen tourist destinations available in five different countries analyzed 5789 travel packages offered by various European tour operators. The holiday packages were analyzed in terms of various variables, including the incentives and promotions offered by the operators to the tourists; the research results concluded that the numbers of incentives and promotions offered by the holiday operators significantly impacted the purchasing decision and travel behavior of the tourists [95]. Similarly, the availability of information regarding holiday packages, including coupon offers and money off, is suggested to be facilitating travelers in conducting the benefit evaluation of the promotional offers and offered incentives, which results in a favorable impact on customers' 
holiday packages and purchase intentions [91]. Likewise, the relationship between various types of incentives in increasing traffic at tourism destinations has also been validated in the literature. A study on a Swiss ski destination revealed that reductions in the ski prices resulted in increased overnight stays at the ski destination hotels and resorts in Switzerland [96]. Hence, the present study's second hypothesis was formulated as follows:

Hypothesis 2 (H2). Travel incentives positively moderate the relationship between CBDS and vaxication intention.

\subsubsection{Moderating Effects of Travel Shaming}

The introduction of travel-shaming behavior towards people who opted to travel to places and countries during the pandemic reveals a major shift in the attitude of the public. This attitude shift is a result of anti-mobility and anti-social interaction campaigns by the WHO and countries, people's understanding of the pandemic situation, and their pursuit of social desirability [14,17]. Travel shaming is a relatively new concept in the tourism literature; however, a prior popular shaming concept related to the travel and aviation industry is stated in the literature as 'flight shaming', and was advocated for its considerable impact on travel intention. Flight shaming refers to an environmental protection campaign called 'flygskam'; an anti-flying movement criticizing airlines and travelers for adversely impacting the environment [97]. The literature presents diverse views about the significance of flight shaming and its potential serious impact on the flying behaviors and air-travel desires of people; however, there is consensus on the understanding that flight shaming most certainly affects social and moral norms, enhances awareness, and interferes with the planning and evaluation process while making a travel decision [98-100]. A study conducted by Winter et al. [100] on 847 participants validated the theory that flight-shaming campaigns negatively impacted the willingness to travel in the future, and successfully built awareness about airlines adversely contributing to climate change; the willingness to travel for participants with high sustainability values was reported to be impacted more compared to those with lower sustainability values. Likewise, another study suggested that flight shaming might not become a mainstream factor instigating significant implications for airline business and operations; however, it certainly is responsible for instilling eco-guilt in the travelers and inducing an emotional pressure for the evaluation and rethinking of their travel choices and behavior [99].

Similarly, consumer behavior literature validates the use of negative emotions (i.e., shame, guilt, fear, and anger) as making a significant contribution to the purchase decisionmaking process. A study on the impact of negative emotions on the purchase decision based on the hierarchy effect model (HEM) suggested that shame was the strongest influencing factor at two out of the six HEM stages (the awareness stage and the conviction to purchase stage); at the awareness stage, the shame of not having the awareness about the product led to the intention to collect the useful information, whereas at the conviction to purchase stage, shame acted as a stimulus for the need to relate to, and not deviate from, the relevant social class [101]. Likewise, the concept of shame has also been attested for its use in social marketing, aiming at persuading people to alter their undesirable social behaviors towards commonly acceptable social behaviors [102,103]. A study conducted on the behaviors of smokers concluded that the use of shame appeal successfully results in a desirable altered behavior (quitting smoking) in smaller communities with supportive legislative systems [102]. Similarly, in another study, the use of negative appeals (fear, shame, and guilt) was postulated as an instrument to create an emotional imbalance, the result of which was reported to be compliance with the desired social behavior [103]. Their results showed that shame should be considered to be an outcome of guilt, and was meaningfully influential in shaping and altering consumer's behavior towards social messages; the study also suggested further research on the underdeveloped theory of shame appeal being potentially capable of significantly affecting social messages and campaigns. As was evident in prior literature, the relevant shaming concepts related to travel, aviation, tourism, 
and consumer behavior have a significant impact on travelers' psychology, intentions, and decision-making processes; it is therefore postulated that for this study, travel shaming will have a similar impact on the destination choices and vaxication decision of the travelers. Hence, the present study's third hypothesis was formulated as follows:

Hypothesis 3 (H3). Travel shaming negatively moderates the relationship between CBDS and vaxication intention.

\section{Methods}

\subsection{Sampling and Procedure}

The present study recruited fully-vaccinated residents in Hawaii, United States for the purpose of the empirical examination of the effects of CBDS on vaxication intention, under the moderating influence of travel shaming and travel incentives. Hawaii is an international tourism hotspot due to its incredible natural beauty (e.g., world-famous white sandy beaches, volcanic activity, and tropical weather), tourism activities (e.g., water sports, especially snorkeling and scuba diving) and unique cultures (e.g., diverse-cuisine and hula dance, etc.), which attracted 10.4 million pre-pandemic visitors in 2019 (generating USD 17.75 Billion tourism revenues), and ironically welcomed 2.7 million post-pandemic visitors in 2020 [104]. A total of 885,913 residents in Hawaii (i.e., 62.57\% of the total population) have already been fully-vaccinated; hence, they can freely enjoy inter-island unrestricted travel, as well as partially-restricted travel to destinations outside Hawaii [104]. In order to generate an adequate study sample of fully-vaccinated residents in Hawaii, the researchers used direct personal contacts through emails and social media platforms (e.g., Facebook and LinkedIn), as well as recruiting survey respondents through the highly-experienced OmniTrak Group. A standardized online-survey design and specific vaxication questions ensured that only fully-vaccinated residents in Hawaii were encouraged to participate in the survey, whereas the non-vaccinated or partially vaccinated residents were automatically screened out [105]. A total of 560 fully-vaccinated residents in Hawaii voluntarily agreed to participate in the online vaxication survey. A pilot study was conducted on the initial sample $(\mathrm{N}=70)$ to ensure that the participants clearly understood the vaxication survey requirements and the stated questions. Importantly, the researchers carefully ensured various procedural remedies (e.g., the anonymity of respondents, the confidentiality of their responses, the lack of the respondent's awareness about the conceptualized model, and informing respondents that they were no right or wrong answers) to overcome any possible issues concerning common method bias [105,106]. None of the questionnaires were discarded, as all of the mandatory question items were completed by the participants successfully. A sample size of 560 fully-vaccinated residents in Hawaii was considered highly sufficient based on the various recommendations and the yardstick for co-variancebased structural equation modeling (CB-SEM) [105].

\subsection{Measures}

The present study relied on mainstream tourism literature on destination branding $[3,4,9]$, destination safety $[5-7,10]$ and COVID-19 tourism $[1,2,8,11,12]$ to develop the measure for CBDS [1-12]. Likewise, the measures for travel shaming [4,24], travel incentives $[18,19,107-109]$, and vaxication intention $[13,16,43,110]$ were also developed based on prominent studies, as well as expert recommendations, including three tourism professors and four tourism practitioners who carefully evaluated the content validities for all of the scale items [105]. The study participants recorded their responses on all of the survey questions (except for their demographic information) on a 5-point Likert scale (i.e., $1=$ strongly disagree to $5=$ strongly agree). Based on the expert feedback, the final version of the measures for CBDS (comprising 10 items, i.e., CBDS1 to CBDS10), travel shaming (comprising 4 items, i.e., TS1 to TS4), travel incentives (comprising 9 items, i.e., TI1 to TI9), and vaxication intention (comprising 4 items, i.e., VI1 to VI4) were also pre-tested in the pilot study $(\mathrm{N}=70)$ for scale reliability (including an internal-consistency reliability check 
with Cronbach's alpha and composite reliability) and scale validity (including discriminant and convergent validity) [105].

\subsection{Data Analysis}

The present study's hypotheses were empirically tested through the widely-applied covariance-based structural equation modeling (CB-SEM) technique, coupled with Mplus, i.e., a fully-integrated modeling program offering more robust SEM estimations in contrast to other competing and commonly used software (e.g., LISREL, EQS, and AMOS, etc.) [111-113]. The data analysis procedures involved statistical estimations in three stages, including: (1) normal distribution testing (using skewness and kurtosis values), (2) measurement model testing (using reliability and validity assessments to ensure the scale's psychometric properties, and exploratory and confirmatory factor analysis to ensure adequate factorialstructure design and model fitness), and (3) structural model testing (using a bootstrapping procedure to ascertain path-coefficients, t-statistics and $p$-values) $[111,113]$.

\section{Results}

\subsection{Demographic Outcomes}

During the analysis, the respondents' demographics were examined prior to the assessment of the hypothesized relationships between the latent constructs. Based on the available secondary data for Hawaii, the results reflected a slight-to-good match between the Hawaiian population and the sample adopted in the present study. According to the Hawaiian census, Hawaiians who are equal to or older than 55 years old constituted $33 \%$ of the population in 2020 [104]. Similarly, the proportion of the same age interval in this study was found to be $34.5 \%$ percent, thus illustrating a match between the sample and the overall population (Table 1 represents the sample demographics). Likewise, in the study sample, the age interval between 18 and 24 years old comprised the smallest group in the Hawaiian population based on the age intervals adopted in the present study [104]. However, the study sample was recognized to be more educated than the original Hawaiian population, where only 33\% have bachelors' or higher degrees. Furthermore, the participants selfreported that they travel at least once a year and stay overnight at hotels. Given the fact that all of the participants have the habit of traveling inside (i.e., inter-island) and outside Hawaii, the sample was deemed to sufficiently reflect the Hawaii population in order to investigate the research objectives [105].

Table 1. Demographic profiles $(N=560)$.

\begin{tabular}{|c|c|c|c|}
\hline Items & & Frequency & Percentage \\
\hline \multirow{3}{*}{ Gender } & Male & 192 & $34.3 \%$ \\
\hline & Female & 358 & $63.9 \%$ \\
\hline & Prefer not to say & 10 & $1.8 \%$ \\
\hline \multirow{5}{*}{ Age } & $18-24$ years & 65 & $11.6 \%$ \\
\hline & 25-34 years & 74 & $13.2 \%$ \\
\hline & $35-44$ years & 107 & $19.1 \%$ \\
\hline & 45-54 years & 121 & $21.6 \%$ \\
\hline & 55 years and above & 193 & $34.5 \%$ \\
\hline \multirow{3}{*}{ Marital Status } & Single & 247 & $44.1 \%$ \\
\hline & Married & 296 & $52.9 \%$ \\
\hline & Prefer not to say & 17 & $3.0 \%$ \\
\hline \multirow{4}{*}{ Education Status } & High School or below & 120 & $21.4 \%$ \\
\hline & Bachelor's Degree (or equivalent) & 277 & $49.5 \%$ \\
\hline & Master's Degree (or equivalent) & 132 & $23.6 \%$ \\
\hline & Doctoral Degree (or equivalent) & 31 & $5.5 \%$ \\
\hline
\end{tabular}


Table 1. Cont.

\begin{tabular}{cccc}
\hline Items & & Frequency & Percentage \\
\hline \multirow{3}{*}{ Annual Income } & $\$ 25,000$ or less & 71 & $12.7 \%$ \\
& $\$ 25,001-\$ 50,000$ & 91 & $16.3 \%$ \\
& $\$ 50,001-\$ 75,000$ & 127 & $22.7 \%$ \\
& $\$ 75,001-\$ 100,000$ & 109 & $19.5 \%$ \\
Frequency of vacation travel & $\$ 100,001-\$ 150,000$ & 102 & $18.2 \%$ \\
before COVID-19 & $\$ 150,001-\$ 200,000$ & 30 & $5.4 \%$ \\
& $\$ 200,001-\$ 250,000$ & 19 & $3.4 \%$ \\
& $\$ 250,001$ or more & 11 & $2.0 \%$ \\
\hline \multirow{2}{*}{ Hotel Nights of Stay } & Once or twice per year & 378 & $67.5 \%$ \\
& Three to five times per year & 157 & $28.0 \%$ \\
& More than five times per year & 25 & $4.5 \%$ \\
\hline & $1-5$ nights & 311 & $55.5 \%$ \\
& $6-10$ nights & 165 & $29.5 \%$ \\
& $11-15$ nights & 54 & $9.6 \%$ \\
& More than 15 nights & 30 & $5.4 \%$ \\
\hline \multirow{2}{*}{ Preferred Vacation Activities } & Natural Scenery & 60 & $10.7 \%$ \\
& Historical/Cultural heritage & 88 & $15.7 \%$ \\
& Entertainment and shopping & 131 & $23.4 \%$ \\
& Outdoor activities & 79 & $14.1 \%$ \\
& Attending festivals & 12 & $2.1 \%$ \\
& Visiting friends and relatives & 164 & $29.3 \%$ \\
& Other & 26 & $4.6 \%$ \\
\hline
\end{tabular}

\subsection{Data Normality and Harman's Single Factor (HSF) Test for Common Method Bias}

In the first phase of the analysis, the research data were examined in terms of outliers, normality, missing data, and other linearity issues. In order to assure that the research data were fit for linear modeling, the data normality was assessed for each latent construct utilized in the model. Table 2 provides information about each construct's normality, wherein the standard deviation for each variable lies within the "-2 and 2" acceptance threshold. Besides this, the skewness values for each latent construct were found between the cut-off acceptance values of " -1 and +1 ". The kurtosis values were also within the acceptance level of " -3 and +3 ". Consequently, all of the latent constructs included in the study were deemed to satisfy the normality assumptions of the structural equation modeling [111-113].

Table 2. Descriptive statistics and data normality test $(\mathrm{N}=560)$.

\begin{tabular}{cccccccccc}
\hline \multirow{2}{*}{ Variables } & $\mathbf{N}$ & Min & Mean & Max & SD & \multicolumn{2}{c}{ Skewness } & \multicolumn{2}{c}{ Kurtosis } \\
\cline { 2 - 10 } & Stats & Stats & Stats & Stats & Stats & Stats & Std. Error & Stats & Std. Error \\
\hline CBDS & 560 & 1.00 & 4.399 & 5.00 & 0.79180 & -0.885 & 0.103 & 0.416 & 0.206 \\
TS & 560 & 1.00 & 3.455 & 5.00 & 0.25600 & -0.498 & 0.103 & -0.772 & 0.206 \\
TI & 560 & 1.00 & 2.675 & 5.00 & 0.12233 & 0.389 & 0.103 & -0.727 & 0.206 \\
VI & 560 & 1.00 & 3.871 & 5.00 & 0.28122 & -0.867 & 0.103 & -0.481 & 0.206 \\
\hline
\end{tabular}

The statistical estimations (as reported in Table 3) determined the common method bias $(\mathrm{CMB})$ using the widely employed Harman's single factor test. A principal component factor (PCF) analysis was executed to identify any existent bias in the study data $(\mathrm{N}=560)$. The PCF analysis (using a single-fixed factor) of all of the latent construct items reported a variance of CMB less than the recommended range of $50 \%$. The PCF analysis clearly established that the estimated variance of $27 \%$ was within the permissible range. Hence, there are no reported CMB issues and/or concern for the present study [111,112]. 
Table 3. Harman's single factor test for common method bias $(\mathrm{N}=560)$.

\begin{tabular}{|c|c|c|c|c|c|c|}
\hline \multirow{2}{*}{ Component } & \multicolumn{3}{|c|}{ Initial Eigenvalues } & \multicolumn{3}{|c|}{ Extraction Sums of Squared Loadings } \\
\hline & Total & $\%$ of Variance & Cumulative $\%$ & Total & $\%$ of Variance & Cumulative $\%$ \\
\hline 1 & 7.473 & 27.679 & 27.679 & 7.473 & 27.679 & 27.679 \\
\hline 2 & 5.861 & 21.706 & 49.385 & & & \\
\hline 3 & 3.219 & 11.922 & 61.307 & & & \\
\hline 4 & 2.721 & 10.077 & 71.384 & & & \\
\hline 5 & 0.823 & 3.049 & 74.433 & & & \\
\hline 6 & 0.774 & 2.868 & 77.301 & & & \\
\hline 7 & 0.753 & 2.789 & 80.090 & & & \\
\hline 8 & 0.626 & 2.320 & 82.410 & & & \\
\hline 9 & 0.519 & 1.922 & 84.332 & & & \\
\hline 10 & 0.477 & 1.767 & 86.098 & & & \\
\hline 11 & 0.413 & 1.528 & 87.626 & & & \\
\hline 12 & 0.396 & 1.466 & 89.092 & & & \\
\hline 13 & 0.331 & 1.226 & 90.318 & & & \\
\hline 14 & 0.309 & 1.143 & 91.462 & & & \\
\hline 15 & 0.276 & 1.021 & 92.482 & & & \\
\hline 16 & 0.267 & 0.989 & 93.471 & & & \\
\hline 17 & 0.254 & 0.942 & 94.414 & & & \\
\hline 18 & 0.239 & 0.884 & 95.298 & & & \\
\hline 19 & 0.218 & 0.806 & 96.104 & & & \\
\hline 20 & 0.191 & 0.706 & 96.810 & & & \\
\hline 21 & 0.177 & 0.654 & 97.465 & & & \\
\hline 22 & 0.159 & 0.591 & 98.055 & & & \\
\hline 23 & 0.152 & 0.564 & 98.619 & & & \\
\hline 24 & 0.136 & 0.504 & 99.124 & & & \\
\hline 25 & 0.113 & 0.419 & 99.543 & & & \\
\hline 26 & 0.075 & 0.278 & 99.821 & & & \\
\hline 27 & 0.048 & 0.179 & 100.000 & & & \\
\hline
\end{tabular}

Notes: Extraction method with principal component analysis.

\subsection{Measurement Model}

After establishing the normally distributed study data, exploratory factor analysis was subsequently conducted. All of the construct items reflected adequate factor loading values (i.e., greater than 0.5), which yielded four distinct constructs with Cronbach's alpha values over 0.90. After the EFA, CFA was employed to assess the extent of the fit between the theoretical model and actual observed data (graphically represented as Figure 1). The goodness of fit indexes provided adequate assurance that the data had a very good fit with the measurement model $\left(\chi^{2} / \mathrm{df}=2.353\right.$, SRMR $=0.067$, RMSEA $\left.=0.049\right)$. Statistical estimations regarding the exploratory and confirmatory factor analyses are depicted in Table 4. Furthermore, Table 4 provides the composite reliability (CR) and average variance extracted (AVE) values of the latent constructs used in the present study. Because the AVE values were higher than the cut-off value of 0.5 , and the $C R$ values were far above the minimum acceptance value of 0.6 , each construct employed in the study was also deemed to successfully achieve convergent validity $[111,113]$.

The non-existent multicollinearity among latent constructs is considered to be necessary to ensure the accuracy of SEM results [111-113]. In order to ascertain the multicollinearity issues (if any), the AVE square root values were compared with the measurement error-adjusted inter-construct correlations, as illustrated in Table 5. Because the square roots of AVE (represented as bold values in Table 5) were much higher than the inter-construct correlations, the variance in all of the constructs was deemed to be explained by their reflective indicators, rather than other composite variables [114]. Consequently, all of the latent constructs in the measurement model established sufficient discriminant validities [111,113]. 


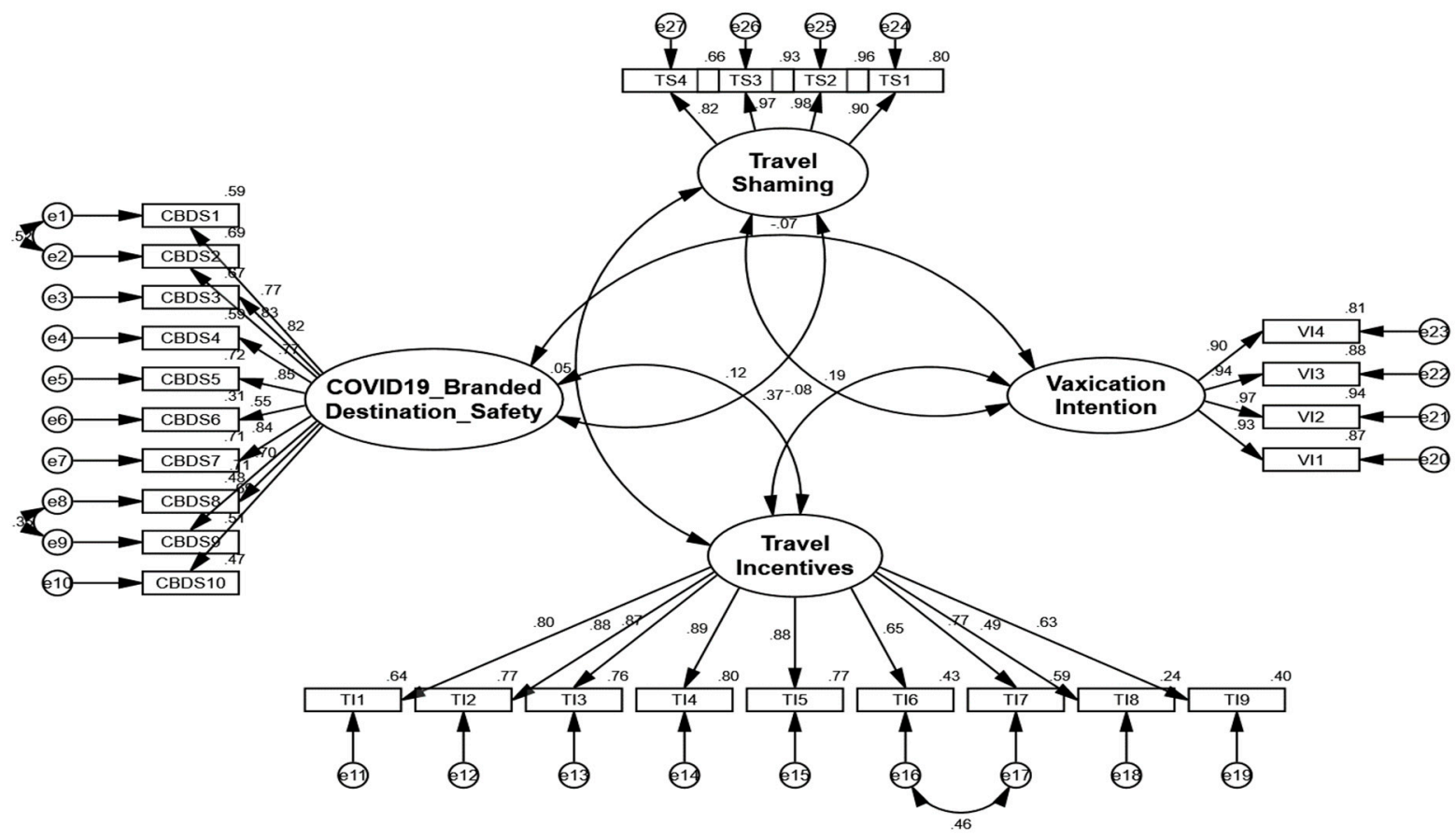

Figure 1. Confirmatory factor analysis (CFA).

Table 4. Measurement model $(\mathrm{N}=560)$

\begin{tabular}{|c|c|c|c|}
\hline Constructs \& Items & Label & $\rho$ & $\lambda$ \\
\hline \multicolumn{4}{|l|}{ COVID-19 Branded Destination Safety (CBDS) } \\
\hline \multicolumn{4}{|l|}{$(C R=0.931 ; A V E=0.575 ;$ Cronbach's Alpha $=0.928)$} \\
\hline \multicolumn{4}{|l|}{ I prefer a tourism destination brand that ensures ... } \\
\hline Visitor's health and safety from COVID-19 throughout their stay. & CBDS1 & 0.814 & 0.767 \\
\hline Health and safety protocols to control the COVID-19 spread. & CBDS2 & 0.873 & 0.832 \\
\hline COVID-19 health screening at airports (e.g., temperature checks, and vaccination proof, etc.). & CBDS3 & 0.824 & 0.820 \\
\hline Adequate post-arrival quarantine for visitors. & CBDS4 & 0.738 & 0.771 \\
\hline Social distancing measures and wearing of masks. & CBDS5 & 0.848 & 0.848 \\
\hline Availability of hand sanitizers in public areas. & CBDS6 & 0.578 & 0.554 \\
\hline Effective contact tracing mechanism for COVID-19. & CBDS7 & 0.842 & 0.843 \\
\hline Wider availability of COVID-19 testing facilities. & CBDS8 & 0.677 & 0.695 \\
\hline $\begin{array}{l}\text { COVID-19 emergency response system (e.g., paramedic services, healthcare facilities } \\
\text { and communications). }\end{array}$ & CBDS9 & 0.709 & 0.712 \\
\hline Mass vaccination campaigns. & CBDS10 & 0.667 & 0.688 \\
\hline \multicolumn{4}{|l|}{ Travel Incentives (TI) } \\
\hline \multicolumn{4}{|l|}{$(C R=0.930 ; A V E=0.599 ;$ Cronbach's Alpha $=0.929)$} \\
\hline \multicolumn{4}{|l|}{ I think that the tourism destinations should offer... } \\
\hline Travel promotions to visitors (e.g., discounted, subsidized, or free flights). & TI1 & 0.796 & 0.801 \\
\hline Free entry to tourist sites (e.g., museums, and archeological sites). & TI2 & 0.894 & 0.878 \\
\hline Free of charge services (e.g., umbrellas, chairs, and sunbeds at famous beaches). & $\mathrm{TI} 3$ & 0.881 & 0.872 \\
\hline Free night(s) of stay for every paid night of accommodation. & TI4 & 0.894 & 0.892 \\
\hline Vouchers for local attractions. & TI5 & 0.880 & 0.879 \\
\hline $\begin{array}{l}\text { Compensation for travel and medical expenses to visitors who contract COVID-19 at } \\
\text { host destination. }\end{array}$ & TI6 & 0.660 & 0.652 \\
\hline Refunds for visitors who bring along their companion (e.g., friends and/or family). & TI7 & 0.784 & 0.769 \\
\hline Flexible booking and accommodation policies. & TI8 & 0.471 & 0.489 \\
\hline Visa waiver and visa-free entry. & TI9 & 0.615 & 0.629 \\
\hline
\end{tabular}


Table 4. Cont.

\begin{tabular}{|c|c|c|c|}
\hline Constructs \& Items & Label & $\rho$ & $\lambda$ \\
\hline \multicolumn{4}{|l|}{ Travel Shaming (TS) } \\
\hline \multicolumn{4}{|l|}{$(C R=0.954 ; A V E=0.840 ;$ Cronbach's Alpha $=0.952)$} \\
\hline \multicolumn{4}{|l|}{ Because I have been fully vaccinated, I fear that I would be criticized by others ... } \\
\hline If I plan for a vacation to a destination that is still experiencing the COVID-19 pandemic. & TS1 & 0.901 & 0.895 \\
\hline If I go for a vacation to a destination that is still experiencing the COVID-19 pandemic. & TS2 & 0.980 & 0.979 \\
\hline If I am on a vacation to a destination that is still experiencing the COVID-19 pandemic. & TS3 & 0.971 & 0.967 \\
\hline $\begin{array}{l}\text { If I share photos of my vacation travel on social media (e.g., Instagram, Facebook, etc.) from a } \\
\text { destination that is still experiencing the COVID-19 pandemic. }\end{array}$ & TS4 & 0.800 & 0.815 \\
\hline \multicolumn{4}{|l|}{ Vaxication Intention (VI) } \\
\hline \multicolumn{4}{|l|}{$(C R=0.965 ; A V E=0.872 ;$ Cronbach's Alpha $=0.964)$} \\
\hline \multicolumn{4}{|l|}{ As I am fully vaccinated for COVID-19 ... } \\
\hline I plan to go on a vacation in the near future. & VI1 & 0.932 & 0.930 \\
\hline I will make an effort to go on a vacation in the near future. & VI2 & 0.962 & 0.967 \\
\hline I have an intention to go on a vacation in the near future. & VI3 & 0.934 & 0.937 \\
\hline I am willing to go on a vacation in the near future. & VI4 & 0.894 & 0.899 \\
\hline \multicolumn{4}{|l|}{ Measurement model fit statistics: } \\
\hline \multicolumn{4}{|l|}{ a. Absolute fit indices } \\
\hline \multirow{2}{*}{\multicolumn{4}{|c|}{$\begin{array}{l}\chi^{2}=741.054, \mathrm{df}=315, p=0.000, \chi^{2} / \mathrm{df}=2.353, \mathrm{SRMR}=0.067, \mathrm{RMSEA}=0.049 \\
b . \text { Incremental fit indices }\end{array}$}} \\
\hline & & & \\
\hline $\mathrm{TLI}=0.965$, and $\mathrm{CFI}=0.968$ & & & \\
\hline
\end{tabular}

Notes: $\rho=$ factor loadings at 0.40 using EFA; $\lambda=$ standardized factors loadings using CFA; $a=$ Cronbach's alpha; CR = composite reliability; AVE $=$ average variance extracted.

Table 5. Multicollinearity and discriminant validity $(\mathrm{N}=560)$.

\begin{tabular}{ccccc}
\hline & CBDS & TI & VI & TS \\
\hline CBDS & $\mathbf{0 . 7 5 8}$ & & & \\
TI & 0.124 & $\mathbf{0 . 7 7 4}$ & & \\
VI & -0.066 & 0.192 & $\mathbf{0 . 9 3 4}$ & $\mathbf{0 . 9 1 6}$ \\
TS & 0.371 & 0.051 & -0.084 &
\end{tabular}

Notes: The bold characters represent the square root of the AVE scores for each construct. The numbers below the diagonals are the values for the measurement-adjusted inter-construct correlations.

\subsection{Structural Model}

Having verified that all of the constructs had good levels of scale, discriminant and convergent validities, path analysis was employed to test the hypothesized relationships among the constructs [113]. The hypotheses' results included path coefficients, $\mathrm{t}$-stats and p-values [111,112], as illustrated in Table 6 and graphically presented in Figure 2. The structural model assessments facilitated the addressing of the present study's main research objective (i.e., the identification of the significant predictors of vaxication intentions amidst the COVID-19 pandemic). The SEM results validated the positive effect of CBDS on vaxication intention, which was found to be statistically significant $(\beta=0.188 ; \mathrm{t}=2.083$; $p<0.05)$, confirming the acceptance of H1. This implies that if a destination is promoted as offering a COVID-19-free and safe atmosphere, this will increase individuals' motivation to travel to that destination soon after getting the necessary vaccine shots. This influence (i.e., the relationship between CBDS and vaxication intention) was also found to be positively moderated by destinations' travel incentives. In particular, the presence of travel incentives augmented the relationship between CBDS and vaxication intention in a statistically significant way $(\beta=0.214 ; \mathrm{t}=4.755 ; p<0.01)$, supporting the acceptance of $\mathrm{H} 2$. Last but not least, a significant moderating influence of travel shaming on the relationship between CBDS and vaxication intention was established. The findings suggest that the feeling of shame that arises from traveling while the pandemic is not yet saturated can negatively influence vaxication intention despite CBDS; hence, $\mathrm{H} 3$ was also accepted $(\beta=-0.148 ; \mathrm{t}=3.020 ; p<0.01)$. 
In other words, despite getting vaccinated, individuals' negative emotions are likely to surpass the effect of destinations' promotional and CBDS efforts.

Table 6. Results of the study hypotheses.

\begin{tabular}{ccccccc}
\hline Hypotheses & Relationships & Path Coefficients & Standard Error (S.E) & $\boldsymbol{t}$-Stats & $\boldsymbol{p}$-Values & Outcomes \\
\hline$H 1$ & CBDS $\rightarrow$ VI & $0.188^{*}$ & 0.090 & 2.083 & 0.037 & Accepted \\
$H 2$ & CBDS * TI $\rightarrow$ VI & $0.214^{* *}$ & 0.045 & 4.755 & 0.000 & Accepted \\
$H 3$ & CBDS TS $\rightarrow$ VI & $-0.148^{* *}$ & 0.049 & -3.020 & 0.000 & Accepted \\
\hline
\end{tabular}

Notes: ${ }^{*} p<0.05 ; * *<0.01$; CBDS $*$ TI $\rightarrow$ VI represents the TI interaction term with a moderating effect on CBDS $\rightarrow$ VI; CBDS * TS $\rightarrow$ VI represents the TS interaction term with a moderating effect on CBDS $\rightarrow$ VI.

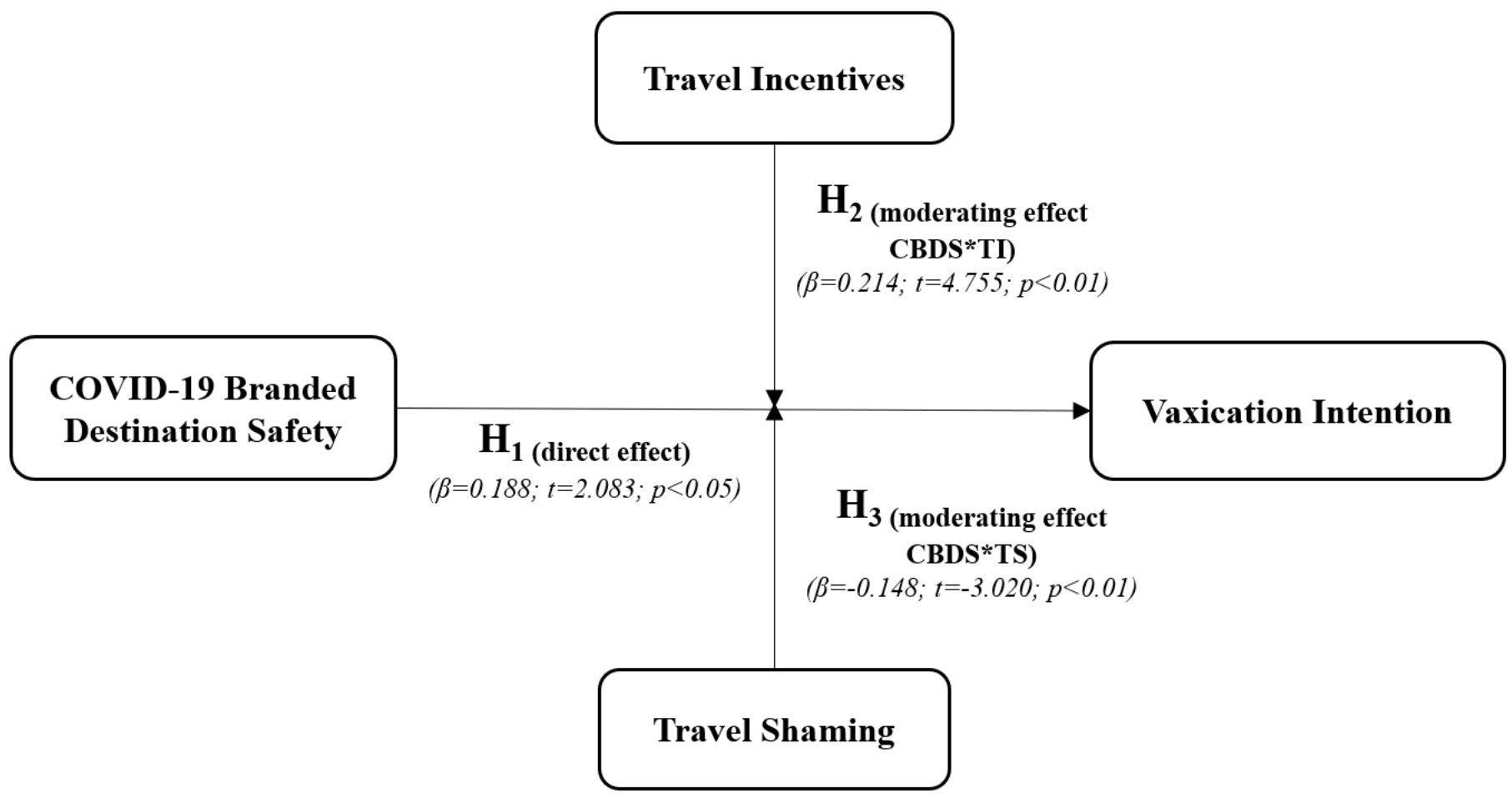

Figure 2. Structural model of vaxication intention.

\section{Discussion}

Despite the unsettling impacts of COVID-19 on destinations, nearly shutting down global tourism, the severity has recently eased due to mass vaccination campaigns, increased public awareness, and strictly applied measures [115]. While they are preparing to host long-awaited visitors again, destinations are trying to position themselves as safe and posing little-to-no risk related to the pandemic $[116,117]$. The present study explored the branding influence of tourism destinations' safety $[5,118]$ on vaxication intention [13], thus constituting a preliminary effort to investigate the relationship between recent trends in tourism [23]. Furthermore, the present study also examined the moderating influence of travel shaming and travel incentives on the relationship between COVID-19-free destination brands and vaxication intention $[4,18,75]$. Structural equation modeling was applied to test and validate the hypothesized relationships in a holistic model of vaxication intention. The findings revealed that when destinations are perceived as pandemic-free brands, the vaxication intention was significantly amplified. Hence, the present study provided empirical evidence to support recent studies that highlight a negative relationship between the perceived health risk of COVID-19 and tourists' revisiting intentions $[119,120]$. Similarly, the findings also complement recent tourism studies that have manifested perceived health 
risks as a major concern for travelers regarding the revisiting of their preferred destinations during the pandemic [121,122].

The present study also assessed whether travel incentives could be useful in driving tourists' attention towards destinations that were hardly hit by the pandemic. The findings unveiled that travel incentives amplify the impact of CBDS on vaxication intention, which underlines the relevance of promotional incentives in destinations' recovery efforts [108]. Thus, this study affirms the extant literature that has highlighted the vital role of tourism promotions to enhance the image of a destination despite some initial negative perceptions [61]. In particular, as suggested by Novelli et al. [49], the present study confirmed that travel incentives (e.g., discounted hotel rates or subsidized flights) could be an effective medium to generate tourist demand, while public health risk is elevated during the global health and tourism crisis $[16,61]$.

Last but not least, the present study also examined the moderating role of travel shaming, wherein the positive impact of CBDS on vaxication intention was significantly altered, with an increasing fear of travel shaming [4]. This finding aligns with the recent movement of "flight shaming", which shows that increasing awareness about the environmental effects of flying can hinder peoples' motivation to travel abroad [97,99]. Likewise, traveling during the pandemic is considered dangerous by many, especially considering the high risk to public health due to the more contagious COVID-19 'delta and omicron' variants. Such emerging risks propelled by new variants of COVID-19 have given rise to emotions of shame for someone who travels irresponsibly $[14,121]$. Consequently, fully-vaccinated travelers may still worry about others' judgment, which can undermine their willingness to travel, even if the destination claims to be COVID-19 free [16].

\subsection{Theoretical Implications}

The present study expands the existent tourism literature and makes significant theoretical contributions by offering the first empirical evidence on post-vaccination travel intention (i.e., vaxication), which is an emerging global tourism phenomenon, though it is rarely examined $[3,6,13,16,23,73]$. The present study also fills the critical knowledge gap on the travel intentions of fully-vaccinated travelers, especially during the times of the COVID-19 pandemic crisis with its emerging new and highly contagious variants (i.e., delta and omicron) $[3,4,12,21-23,73]$. Because the ongoing pandemic has nearly placed global tourism at a standstill, it has urged many destinations to develop cutting-edge strategies to regain tourists' confidence and revive inbound tourism $[1,9,12]$. The present study advances the tourism literature with a novel theoretical framework and sheds light on tourists' cognitive evaluation of destinations that are deemed to be under crisis [13,23]. Importantly, the present study introduces the theory of planned behavior and protection motivation theory to tourism literature by presenting a novel model that conceptualizes the most recent trends and challenges in global tourism (i.e., CBDS, travel shaming, redesigned travel incentives and vaxication) $[4,119,122,123]$. Drawing upon the protection motivation theory, the study findings suggest that those destinations promoting themselves as COVID19 free can positively attract more visitors [16]. Furthermore, this study empirically verified the moderating role of travel shaming, contributing to the scholarly understanding of emotions in tourism behavior $[4,124]$. The concept of shame was investigated in only a few tourism studies, which have suggested that social pressure may sometimes force travelers to refrain from using flights, favoring environmentally friendly transportation alternatives $[97,99]$. However, these studies concentrated narrowly on flight shaming while overlooking whether the feeling of shame can broadly apply to different aspects of traveling, especially during a time of crisis [4,14]. To that end, this study, for the first time, empirically assessed travel shaming in connection with vaxication intention, extending scholarly knowledge about the underlying role of shame in post-pandemic travel behavior [124]. Last but not least, the present study tested the practicability of travel incentives in increasing the tourist influx to hardly hit tourism destinations during the global pandemic. Although prior literature has highlighted that sales promotions and 
discounts can increase the demand for tourism $[61,125,126]$, no study has yet analyzed the role of tourism incentives in encouraging travel behavior during an ongoing tourism crisis [18]. Therefore, this study makes a novel contribution to the literature by highlighting the fact that tourism incentives can augment peoples' intentions to travel after being fully vaccinated $[13,108]$.

\subsection{Managerial Implications}

Based on the study findings, the present study offers valuable insights to destination management organizations struggling to survive the COVID-19 pandemic. First, the present study provided empirical evidence that promoting destinations as pandemic-free can augment post-pandemic travelers' intentions to visit those destinations. Therefore, it is recommended that destination management organizations underline their capability of offering safe and healthy vacations in their marketing campaigns [127]. One good example of this strategy is employed by the renowned Italian island of Capri, which promotes itself as a COVID-19-free destination, along with highlighting the island's natural trails as an enabler for isolated tourism [128]. Furthermore, this study unveils those incentives employed during a tourism crisis that can facilitate demand and foster tourism recovery. Destinations are advised to filter out the most appropriate incentives and customize offers based on targeted tourists' profiles. For example, incentives such as subsidized flights, booking cancellation without charge, visa waivers, and personalized promotions targeting small niches, etc., can lure some international tourists away from competing destination brands $[65,86]$. Nevertheless, these policies should be coherently coordinated as part of destinations' long-term recovery plans, as tourism services are inherently interdependent [129]. Destinations should also pay more attention to tourists' emotions and the factors affecting travel motivations in their tourism recovery efforts and plans. Since the beginning of the outbreak, uncertainties and echoed health risks have damaged peoples' emotional wellbeing, causing distress to the larger society. Hence, destinations are advised to incorporate the significant shifts in travelers' emotional conditions (e.g., travel shaming) and concerns while designing post-pandemic marketing interventions. For example, if traveling continues to be considered risky and socially inappropriate, it is suggested that destinations develop emotional appeals to positively reframe COVID-19 and increase the public approval of post-vaccination travel $[23,130]$.

Importantly, post-arrival quarantine policies (as a significant indicator of destination safety) can have a varying degree of impact on the travelers, residents and tourism planners $[1,3,16,20,24]$. Hence, branding destinations for COVID-19 safety should be prioritized from the multi-stakeholder perspective, i.e., tourists, residents, and tourism planners, as well as fully-vaccinated, non-vaccinated and partially-vaccinated individuals $[1,3,23]$. Recently, there has been a growing number of tourism destinations (e.g., Spain, Portugal, and Malta) that have allowed quarantine exemptions for fully-vaccinated travelers, whereas non-vaccinated and/or partially-vaccinated travelers still have to undergo the mandatory quarantine period (usually 14 days) on arrival $[2,20]$. Moreover, fully-vaccinated travelers can skip quarantine when returning from non-red-list countries (e.g., New Zealand, Singapore, and Switzerland). Hence, depending on the visitor's COVID-19 vaccination status, quarantine policies can be leveraged to prioritize destination safety, and can use CBDS to attract fully-vaccinated travelers with vaxication intentions $[1,3,11,23,24]$.

\subsection{Limitations and Future Research}

Although this study focused on the most recent global tourism trends (i.e., CBDS, vaxication, and travel shaming), some limitations need to be mentioned. First, this study collected data from Hawaii, the only island state in the United States with a unique native culture. Hawaii is already a famous tourism hotspot, providing its residents with various entertainment and relaxation options within the island [131]. Therefore, the Hawaiians' vaxication tendencies to pandemic-free destinations may not truly represent international tourism behavior $[132,133]$. In order to address this issue, future studies could concentrate 
on countries with diverse economic, social and geographical circumstances to extend the generalizability of the present study findings. Furthermore, as the present study sheds light on recent developments in tourism, for the sake of simplicity, it utilized one of the frequently used theories in tourism, namely the theory of planned behavior and protection motivation theory. Future studies could also draw findings based on additional wellaccepted theories of consumer behavior. For example, the impact of tourism incentives and travel shaming on vaxication intention could be further assessed based on the heuristic systematic model and cognitive response theories [105], which can contribute to the scholarly understanding of post-pandemic tourist behavior. Therefore, it is also advised that future studies take advantage of persuasive theories of emotion and communication in order to better understand and take advantage of travelers' changing intentions through and beyond the COVID-19 pandemic [122].

\section{Conclusions}

With the reopening of international borders and relatively relaxed measures for global travel, destinations worldwide are devising strategies to offset the devastating effects of the pandemic [2]. In order to address this contentious issue, the present study empirically highlighted that promoting destinations as pandemic-free can trigger future tourism demand, especially for those who have already received their vaccination shots. The pandemic has distressed many nations with extremely challenging economic, social and cultural conditions, leaving too many people emotionally damaged [134-136]. Once acknowledged as a social currency, global travel now incites feelings of shame for those who still want to travel during the pandemic [23]. Hence, it is recommended that destination management organizations develop effective mechanisms to track changes and empathize with future travelers' emotions. In particular, destinations can positively frame COVID-19 travel behavior and launch promotional campaigns to enhance the public approval of traveling in the post-pandemic era, especially for fully-vaccinated visitors [130]. Importantly, destination marketers should reconfigure tourism products with realigned travel incentives for vaccinated travelers, as well as re-establishing their destination brand for COVID-19 safety [1]. Lastly, tailored incentives (e.g., Mexico's "Come to Cancun 2X1" campaign) can encourage vaxication as an initiative to revive the global tourism industry to its pre-pandemic level $[2,13]$.

Author Contributions: Conceptualization, U.Z. and M.A. (Murat Aktan); methodology, U.Z. and M.A. (Murat Aktan); software, M.G.K.; validation, U.Z. and M.G.K.; formal analysis, M.G.K.; investigation, U.Z., J.A. and M.G.K.; resources, M.G.K. and U.Z.; data curation, M.A. (Murat Aktan), U.Z. and M.G.K.; writing —original draft preparation, U.Z., M.A. (Murat Aktan), M.A. (Mahwish Anjam), M.G.K., P.F. and J.A.; writing-review and editing, U.Z., M.A. (Murat Aktan), M.G.K., P.F. and J.A.; visualization, M.G.K.; supervision, U.Z. and M.A. (Murat Aktan); project administration, U.Z. All authors have read and agreed to the published version of the manuscript.

Funding: This research received no external funding.

Institutional Review Board Statement: This research was conducted in accordance with the Declaration of Helsinki, and under the approval of the Institutional Review Board of the University of Hawaii (UH) at Manoa, Honolulu, HI 96822, USA (IRB2021-00479 dated 25 May 2021).

Informed Consent Statement: Informed consent was initially obtained from all participants who had volunteered to participate in this study.

Data Availability Statement: The study data is available on special request from the corresponding author.

Conflicts of Interest: The authors declare no conflict of interest. 


\section{References}

1. Fotiadis, A.; Polyzos, S.; Huan, T.-C.T.C. The Good, the Bad and the Ugly on COVID-19 Tourism Recovery. Ann. Tour. Res. 2021, 87, 103117. [CrossRef]

2. Villacé-Molinero, T.; Fernández-Muñoz, J.J.; Orea-Giner, A.; Fuentes-Moraleda, L. Understanding the New Post-COVID-19 Risk Scenario: Outlooks and Challenges for a New Era of Tourism. Tour. Manag. 2021, 86, 104324. [CrossRef]

3. Lee, S.T. Vaccine Diplomacy: Nation Branding and China's COVID-19 Soft Power Play. Place Brand Public Dipl. 2021. [CrossRef]

4. Skinner, H. Place Branding-The Challenges of Getting It Right: Coping with Success and Rebuilding from Crises. Tour. Hosp. 2021, 2, 173-189. [CrossRef]

5. Yen, C.-H.; Tsaur, S.-H.; Tsai, C.-H. Destination Safety Climate: Scale Development and Validation. J. Travel Tour. Mark. 2021, 38, 303-315. [CrossRef]

6. Patwardhan, V.; Ribeiro, M.A.; Payini, V.; Woosnam, K.M.; Mallya, J.; Gopalakrishnan, P. Visitors' Place Attachment and Destination Loyalty: Examining the Roles of Emotional Solidarity and Perceived Safety. J. Travel Res. 2020, 59, 3-21. [CrossRef]

7. Collins, M.D.; Millar, M. Tourists' Perceptions of Destination Image, Safety, and Aggressive Street Behavior. Int. J. Hosp. Tour. Adm. 2021, 22, 251-268. [CrossRef]

8. Gössling, S.; Scott, D.; Hall, C.M. Pandemics, Tourism and Global Change: A Rapid Assessment of COVID-19. J. Sustain. Tour. 2021, 29, 1-20. [CrossRef]

9. Ruiz-Real, J.L.; Uribe-Toril, J.; Gázquez-Abad, J.C. Destination Branding: Opportunities and New Challenges. J. Destin. Mark. Manag. 2020, 17, 100453. [CrossRef]

10. Zou, Y.; Meng, F. Chinese Tourists' Sense of Safety: Perceptions of Expected and Experienced Destination Safety. Curr. Issues Tour. 2020, 23, 1886-1899. [CrossRef]

11. Kock, F.; Nørfelt, A.; Josiassen, A.; Assaf, A.G.; Tsionas, M.G. Understanding the COVID-19 Tourist Psyche: The Evolutionary Tourism Paradigm. Ann. Tour. Res. 2020, 85, 103053. [CrossRef] [PubMed]

12. Lapointe, D. Reconnecting Tourism after COVID-19: The Paradox of Alterity in Tourism Areas. Tour. Geogr. Int. J. Tour. Place Space Environ. 2020, 22, 633-638. [CrossRef]

13. Atsa'am, D.D.; Wario, R. Association Rules on the COVID-19 Variants of Concern to Guide Choices of Tourism Destinations. Curr. Issues Tour. 2021. [CrossRef]

14. Compton, N. Traveling Was Once Social Currency. Now It Might Get You Shamed. The Washington Post, 2021. Available online: https:/ / www.washingtonpost.com/travel/2020/09/01/pandemic-travel-shaming/ (accessed on 11 October 2021).

15. Reid, L. Travel Shaming, Travel Fear, and the Many Challenges the Travel Industry Faces This Year. Brandwatch, 2020. Available online: https: / / www.brandwatch.com/blog/react-travel-shaming/ (accessed on 5 June 2021).

16. Rastegar, R.; Seyfi, S.; Rasoolimanesh, S.M. How COVID-19 Case Fatality Rates Have Shaped Perceptions and Travel Intention? J. Hosp. Tour. Manag. 2021, 47, 353-364. [CrossRef]

17. Snow, B. Here's Something Else to Worry about When You Travel. Fodors, 2021. Available online: https://www.fodors.com/ news / coronavirus / heres-something-else-to-worry-about-when-you-travel (accessed on 3 November 2021).

18. Sigala, M. Tourism and COVID-19: Impacts and Implications for Advancing and Resetting Industry and Research. J. Bus. Res. 2020, 117, 312-321. [CrossRef] [PubMed]

19. Wang, D.; Martin, B.A.S.; Yao, J. Do Discount Presentations Influence Gift Purchase Intentions and Attitudes of Chinese Outbound Tourists? J. Travel Res. 2021, 60, 1104-1122. [CrossRef]

20. Euro, N. Where can I Travel in Europe Right Now? A Complete List of Travel Restrictions. Euronews, 2021. Available online: https: //www.euronews.com/travel/2021/07/14/what-s-the-latest-on-european-travel-restrictions (accessed on 12 November 2021).

21. Hosie, R. All the Countries Offering Incentives to Tourists Post-Coronavirus, from Free Hotel Stays to Spa Vouchers. Insider, 2021. Available online: https:/ / www.insider.com/all-places-offering-discounts-freebies-incentives-entice-tourists-post-coronavirus2020-6 (accessed on 27 October 2021).

22. Mansoor, Z. Dubai Carrier Emirates Offers Year-Long Travel Incentives to Students and Families. Gulf Business, 2021. Available online: https:/ / gulfbusiness.com/dubai-carrier-emirates-offers-year-long-travel-incentives-to-students-and-their-families / (accessed on 22 August 2021).

23. Wang, M.; Kunasekaran, P.; Rasoolimanesh, S.M. What Influences People's Willingness to Receive the COVID-19 Vaccine for International Travel? Curr. Issues Tour. 2021. [CrossRef]

24. Cresswell, T. Valuing Mobility in a Post COVID-19 World. Mobilities 2021, 16, 51-65. [CrossRef]

25. Kotler, P.; Nebenzahl, I.D.; Lebedenko, V.; Rainisto, S.; Gertner, D.; Clifton, R.; van Ham, P.; Kalninš, O.; Morgan, N.; Papadopoulos, N.; et al. 'Where Is Place Branding Heading?'. Place Brand. 2004, 1, 12-35. [CrossRef]

26. Lavidge, R.J.; Steiner, G.A. A Model for Predictive Measurements of Advertising Effectiveness. J. Mark. 1961, 25, 59-62. [CrossRef]

27. Kotler, P.; Gertner, D. Country as Brand, Product, and beyond: A Place Marketing and Brand Management Perspective. J. Brand Manag. 2002, 9, 249-261. [CrossRef]

28. Pritchard, A.; Morgan, N. "Mood Marketing"-The New Destination Branding Strategy: A Case Study of "Wales" The Brand. J. Vacat. Mark. 1998, 4, 215-229. [CrossRef]

29. Madden, K.; Rashid, B.; Zainol, N.A. Beyond the Motivation Theory of Destination Image. Tour. Hosp. Manag. 2016, 22, 247-264. [CrossRef] 
30. Daya, N.J.C.; Chiliya, N. An Assessment of the Public Attitudes towards the Inner City of Johannesburg as a Branded Destination. Mediterr. J. Soc. Sci. 2014, 5, 1473-1481. [CrossRef]

31. Dioko, L.A.N.; So, S.-I. Branding Destinations versus Branding Hotels in a Gaming Destination-Examining the Nature and Significance of Co-Branding Effects in the Case Study of Macao. Int. J. Hosp. Manag. 2012, 31, 554-563. [CrossRef]

32. Horrigan, D. Branded Content: A New Model for Driving Tourism via Film and Branding Strategies. Tour. Int. Multidiscip. Refereed J. Tour. 2009, 4, 51-65.

33. Kolb, B. Tourism Marketing for Cities and Towns: Using Social Media and Branding to Attract Tourists, 2nd ed.; Revised Edition of the Author's Tourism Marketing for Cities and Towns, 2006; Routledge: New York, NY, USA, 2017.

34. Wang, S.; Japutra, A.; Molinillo, S. Branded Premiums in Tourism Destination Promotion. Tour. Rev. 2021, 76, 1001-1012. [CrossRef]

35. Ritchie, J.R.B.; Ritchie, J.R. The branding of tourism destinations: Past Achievements and Future Challenges. Ann. Cong. Int. Ass. Sci. Experts Tour. Marrakech 1998, 1-31.

36. Briciu, V.-A. Differences between Place Branding and Destination Branding for Local Brand Strategy Development. Bull. Transilv. Univ. Braş. 2013, 6, 9-14.

37. Qu, H.; Kim, L.H.; Im, H.H. A Model of Destination Branding: Integrating the Concepts of the Branding and Destination Image. Tour. Manag. 2011, 32, 465-476. [CrossRef]

38. Rowley, J.; Hanna, S. Branding Destinations: Symbolic and Narrative Representations and Co-Branding. J. Brand Manag. 2020, 27, 328-338. [CrossRef]

39. Hsu, C.; Cai, L.A. Brand Knowledge, Trust and Loyalty-A Conceptual Model of Destination Branding. In Proceedings of the International CHRIE Conference-Refereed Track, San Francisco, CA, USA, 31 July 2009; University of Massachusetts Amherst: Amherst, MA, USA, 2009.

40. Roostika, R. Destination Branding and Its Influence on Tourist's Satisfaction and Loyalty. J. Technol. Manag. 2012, 11, 60-74.

41. Chen, C.-F.; Tsai, D. How Destination Image and Evaluative Factors Affect Behavioral Intentions? Tour. Manag. 2007, 28, 1115-1122. [CrossRef]

42. Blain, C.; Levy, S.E.; Ritchie, J.R.B. Destination Branding: Insights and Practices from Destination Management Organizations. J. Travel Res. 2005, 43, 328-338. [CrossRef]

43. Bianchi, C.; Milberg, S.; Cúneo, A. Understanding Travelers' Intentions to Visit a Short versus Long-Haul Emerging Vacation Destination: The Case of Chile. Tour. Manag. 2017, 59, 312-324. [CrossRef]

44. Han, H.; Kim, Y. An Investigation of Green Hotel Customers' Decision Formation: Developing an Extended Model of the Theory of Planned Behavior. Int. J. Hosp. Manag. 2010, 29, 659-668. [CrossRef]

45. Lam, T.; Hsu, C.H.C. Predicting Behavioral Intention of Choosing a Travel Destination. Tour. Manag. 2006, 27, 589-599. [CrossRef]

46. Ajzen, I. The Theory of Planned Behavior. Organ. Behav. Hum. Decis. Process. 1991, 50, 179-211. [CrossRef]

47. Hill, R.J.; Fishbein, M.; Ajzen, I. Belief, Attitude, Intention and Behavior: An Introduction to Theory and Research. Contemp. Sociol. 1977, 6, 244. [CrossRef]

48. Swan, J.E.; Trawick, I.F. Disconfirmation of expectations and satisfaction with a retail service. J. Retail. 1981, 57, 49-67.

49. Novelli, M.; Gussing Burgess, L.; Jones, A.; Ritchie, B.W. “No Ebola ... still Doomed”-The Ebola-Induced Tourism Crisis. Ann. Tour. Res. 2018, 70, 76-87. [CrossRef]

50. UNWTO. World Tourism Barometer and Statistical Annex, May 2020. UNWTO World Tour. Barom 2020, 18, 1-48.

51. Lu, Q.; Atadil, H.A. Do you dare to travel to China? An examination of China's destination image amid the COVID-19. Tour. Manag. Perspect. 2021, 40, 100881. [CrossRef]

52. Han, H.; Al-Ansi, A.; Chua, B.-L.; Tariq, B.; Radic, A.; Park, S.-H. The Post-Coronavirus World in the International Tourism Industry: Application of the Theory of Planned Behavior to Safer Destination Choices in the Case of US Outbound Tourism. Int. J. Environ. Res. Public Health 2020, 17, 6485. [CrossRef]

53. Koh, E. The End of Over-Tourism? Opportunities in a Post-COVID-19 World. Int. J. Tour. Cities 2020, 6, 1015-1023. [CrossRef]

54. Singh, S. 'Quixotic' Tourism? Safety, Ease, and Heritage in Post-COVID World Tourism. J. Herit. Tour. 2021, 16, 716-721. [CrossRef]

55. Bashir, S.; Khwaja, M.G.; Mahmood, A. Mores of the Customer Base for Ecotourism Industry: Development and Validation of a New Measurement Scale. PLoS ONE 2021, 16, e0246410. [CrossRef]

56. Zhu, X.; Wang, F.; Chen, C.; Reed, D.D. Personalized Incentives for Promoting Sustainable Travel Behaviors. Transp. Res. Part C Emerg. Technol. 2020, 113, 314-331. [CrossRef]

57. Bashir, S.; Khwaja, M.G.; Turi, J.A.; Toheed, H. Extension of Planned Behavioral Theory to Consumer Behaviors in Green Hotel. Heliyon 2019, 5, e02974. [CrossRef]

58. Bashir, S.; Khwaja, M.G.; Rashid, Y.; Turi, J.A.; Waheed, T. Green Brand Benefits and Brand Outcomes: The Mediating Role of Green Brand Image. SAGE Open 2020, 10, 215824402095315. [CrossRef]

59. Gilbert, D.C. An Examination of the Consumer Behaviour Process Related to Tourism; Belhaven Press: Hants, UK, 1991 ; pp. 78-105.

60. Dann, G.M.S. Anomie, Ego-Enhancement and Tourism. Ann. Tour. Res. 1977, 4, 184-194. [CrossRef]

61. Campo, S.; Alvarez, M.D. Can Tourism Promotions Influence a Country's Negative Image? An Experimental Study on Israel's Image. Curr. Issues Tour. 2014, 17, 201-219. [CrossRef] 
62. Ghida, C.H.A.N. How to Re-Emerge as a Tourism Destination after a Period of Political Instability. 2021. Available online: https://www3.weforum.org/docs/TT15/WEF_TTCR_Chapter1.3_2015.pdf (accessed on 18 October 2021).

63. Fenich, G.G.; Vitiello, K.L.; Lancaster, M.F.; Hashimoto, K. Incentive Travel: A View from the Top. J. Conv. Event Tour. 2015, 16, 145-158. [CrossRef]

64. Shinew, K.J.; Backman, S.J. Incentive Travel: An Attractive Option. Tour. Manag. 1995, 16, 285-293. [CrossRef]

65. Weed, J. Visa Waivers, Vouchers, Flight Discounts and Other Travel Lures. The New York Times, 8 July 2020. Available online: https://www.nytimes.com/2020/07/08/travel/travel-discounts-vouchers-coronavirus.html (accessed on 23 October 2021).

66. Suman. Travel-Shaming is Happening, but the Opposite Way. Gulte, 2021. Available online: https://www.gulte.com/trends/55 563/travel-shaming-is-happening-but-the-opposite-way (accessed on 14 November 2021).

67. Rogers, R.W. A Protection Motivation Theory of Fear Appeals and Attitude Change1. J. Psychol. 1975, 91, 93-114. [CrossRef]

68. Sutton, S.R. Fear-Arousing Communications: A Critical Examination of Theory and Research. Soc. Psychol. Behav. Med. 1982, 303-337.

69. Bhati, A.S.; Mohammadi, Z.; Agarwal, M.; Kamble, Z.; Donough-Tan, G. Motivating or Manipulating: The Influence of HealthProtective Behaviour and Media Engagement on Post-COVID-19 Travel. Curr. Issues Tour. 2021, 24, 2088-2092. [CrossRef]

70. Qiao, G.; Ruan, W.J.; Pabel, A. Understanding Tourists' Protection Motivations When Faced with Overseas Travel after COVID-19: The Case of South Koreans Travelling to China. Curr. Issues Tour. 2021. [CrossRef]

71. Wang, J.; Liu-Lastres, B.; Ritchie, B.W.; Mills, D.J. Travellers' Self-Protections against Health Risks: An Application of the Full Protection Motivation Theory. Ann. Tour. Res. 2019, 78, 102743. [CrossRef]

72. Conner, M.; Norman, P. Predicting Health Behaviour; McGraw-Hill Education: London, UK, 2015.

73. Phelan, A.L. COVID-19 Immunity Passports and Vaccination Certificates: Scientific, Equitable, and Legal Challenges. Lancet 2020, 395, 1595-1598. [CrossRef]

74. Reid, C. Travel in 2021 will be Better and Worse than You Think. MMYGY Global, 2021. Available online: https://www. mmgyglobal.com/news/travel-in-2021-will-be-better-and-worse-than-you-think/ (accessed on 4 November 2021).

75. Murphy, J. Celebratory 'Vaxications' Are Giving the Travel Industry a Boost. Bloomberg, 2021. Available online: https:// www.bloomberg.com/news/articles/2021-03-07/celebratory-vaxications-are-giving-the-travel-industry-a-boost (accessed on 4 November 2021).

76. Rosenstock, I.M. Historical Origins of the Health Belief Model. Health Educ. Monogr. 1974, 2, 328-335. [CrossRef]

77. Rosenstock, I.M. The Health Belief Model and Preventive Health Behavior. Health Educ. Monogr. 1977, 2, 354-386. [CrossRef]

78. Rosenstock, I.M.; Strecher, V.J.; Becker, M.H. Social Learning Theory and the Health Belief Model. Health Educ. Q. 1988, 15, 175-183. [CrossRef]

79. Zampetakis, L.A.; Melas, C. The Health Belief Model Predicts Vaccination Intentions against COVID-19: A Survey Experiment Approach. Appl. Psychol. Health Well Being 2021, 13, 469-484. [CrossRef] [PubMed]

80. Rabin, C.; Dutra, S. Predicting Engagement in Behaviors to Reduce the Spread of COVID-19: The Roles of the Health Belief Model and Political Party Affiliation. Psychol. Health Med. 2021. [CrossRef] [PubMed]

81. Zhao, J.; An, Y. Behavioural Intention of Forest Therapy Tourism in China: Based on Health Belief Model and the Theory of Planned Behaviour. Curr. Issues Tour. 2021, 24, 3425-3432. [CrossRef]

82. Bansal, H.; Eiselt, H.A. Exploratory Research of Tourist Motivations and Planning. Tour. Manag. 2004, 25, 387-396. [CrossRef]

83. Matiza, T. Post-COVID-19 Crisis Travel Behaviour: Towards Mitigating the Effects of Perceived Risk. J. Tour. Futures 2020. ahead-of-print. [CrossRef]

84. Chang, C.-L.; McAleer, M.; Ramos, V. A Charter for Sustainable Tourism after COVID-19. Sustainability 2020, 12, 3671. [CrossRef]

85. Grech, V.; Grech, P.; Fabri, S. A Risk Balancing Act-Tourism Competition Using Health Leverage in the COVID-19 Era. Int. J. Risk Saf. Med. 2020, 31, 121-130. [CrossRef]

86. Toubes, D.R.; Araújo Vila, N.; Fraiz Brea, J.A. Changes in Consumption Patterns and Tourist Promotion after the COVID-19 Pandemic. J. Theor. Appl. Electron. Commer. Res. 2021, 16, 1332-1352. [CrossRef]

87. Kim, J.; Park, J.; Lee, J.; Kim, S.; Gonzalez-Jimenez, H.; Lee, J.; Choi, Y.K.; Lee, J.C.; Jang, S.; Franklin, D.; et al. COVID-19 and Extremeness Aversion: The Role of Safety Seeking in Travel Decision Making. J. Travel Res. 2021. [CrossRef]

88. Blattberg, R.C.; Briesch, R.; Fox, E.J. How Promotions Work. Mark. Sci. 1995, 14, 122-132. [CrossRef]

89. Nusair, K.; Jin Yoon, H.; Naipaul, S.; Parsa, H.G. Effect of Price Discount Frames and Levels on Consumers' Perceptions in Low-end Service Industries. Int. J. Contemp. Hosp. Manag. 2010, 22, 814-835. [CrossRef]

90. Lee, H.S.; Bai, B. Hotel Discount Strategies on Consumer Responses: The Role of Involvement. Tour. Rev. 2014, 69, $284-296$.

91. Christou, E. Promotional Pricing in the Electronic Commerce of Holiday Packages: A Model of Purchase Behavior. In Information and Communication Technologies in Tourism 2005; Springer: Vienna, Austria, 2005; pp. 463-473.

92. Lo, A.; Qu, H. A Theoretical Model of the Impact of a Bundle of Determinants on Tourists' Visiting and Shopping Intentions: A Case of Mainland Chinese Tourists. J. Retail. Consum. Serv. 2015, 22, 231-243. [CrossRef]

93. Mangion, M.-L.; Durbarry, R.; Sinclair, M.T. Tourism Competitiveness: Price and Quality. Tour. Econ. 2005, 11, 45-68. [CrossRef]

94. Peattie, K.; Peattie, S. Promotional Competitions: A Winning Tool for Tourism Marketing. Tour. Manag. 1996, 17, 433-442. [CrossRef]

95. Picazo, P.; Moreno-Gil, S. Tour Operators' Marketing Strategies and Their Impact on Prices of Sun and Beach Package Holidays. J. Hosp. Tour. Manag. 2018, 35, 17-28. [CrossRef] 
96. Falk, M.; Scaglione, M. Effects of Ski Lift Ticket Discounts on Local Tourism Demand. Tour. Rev. 2018, 73, 480-491. [CrossRef]

97. Chiambaretto, P.; Mayenc, E.; Chappert, H.; Engsig, J.; Fernandez, A.-S.; Le Roy, F. Where Does Flygskam Come from? The Role of Citizens' Lack of Knowledge of the Environmental Impact of Air Transport in Explaining the Development of Flight Shame. J. Air Transp. Manag. 2021, 93, 102049. [CrossRef]

98. Korkea-aho, E. Flight Shame: Shame as a Tool to Change Consumer Behavior, Tampere University of Applied Sciences. 2019. Available online: http:/ / www.theseus.fi/handle/10024/264851 (accessed on 4 November 2021).

99. Mkono, M. Eco-Anxiety and the Flight Shaming Movement: Implications for Tourism. J. Tour. Futures 2020, 6, 223-226. [CrossRef]

100. Winter, S.R.; Lamb, T.L.; Wallace, R.J.; Anderson, C.L. Flight Shaming Consumers into Aviation Sustainability: Which Factors Moderate. Int. J. Sustain. Aviat. 2021, 7, 21. [CrossRef]

101. Koshkaki, E.R.; Solhi, S. The Facilitating Role of Negative Emotion in Decision Making Process: A Hierarchy of Effects Model Approach. J. High Technol. Manag. Res. 2016, 27, 119-128. [CrossRef]

102. Amonini, C.; Pettigrew, S.; Clayforth, C. The Potential of Shame as a Message Appeal in Antismoking Television Advertisements. Tob. Control 2015, 24, 436-441. [CrossRef]

103. Brennan, L.; Binney, W. Fear, Guilt, and Shame Appeals in Social Marketing. J. Bus. Res. 2010, 63, 140-146. [CrossRef]

104. HTA. Hawaii Tourism Authority. 2021. Available online: https://www.hawaiitourismauthority.org/ (accessed on 10 December 2021).

105. Zaman, U.; Aktan, M. Examining Residents' Cultural Intelligence, Place Image and Foreign Tourist Attractiveness: A MediatedModeration Model of Support for Tourism Development in Cappadocia (Turkey). J. Hosp. Tour. Manag. 2021, 46, 393-404. [CrossRef]

106. Podsakoff, P.M.; MacKenzie, S.B.; Lee, J.-Y.; Podsakoff, N.P. Common Method Biases in Behavioral Research: A Critical Review of the Literature and Recommended Remedies. J. Appl. Psychol. 2003, 88, 879-903. [CrossRef]

107. Duman, T.; Mattila, A.S. A Logistic Regression Analysis of Discount Receiving Behavior in the Cruise Industry: Implications for Cruise Marketers. Int. J. Hosp. Tour. Adm. 2003, 4, 45-57. [CrossRef]

108. Ming-Fong Yu, S.; Rong-Da Liang, A.; Lin, C.-J. The Effects of Relative and Referent Thinking on Tourism Product Design. Tour. Manag. 2019, 73, 157-171. [CrossRef]

109. Zhao, X.; Liu, Y.; Bi, H.; Law, R. Influence of Coupons on Online Travel Reservation Service Recovery. J. Hosp. Tour. Manag. 2014, 21, 18-26. [CrossRef]

110. Wu, G.; Liang, L. Examining the Effect of Potential Tourists' Wine Product Involvement on Wine Tourism Destination Image and Travel Intention. Curr. Issues Tour. 2020, 1-16. [CrossRef]

111. Wang, J.; Wang, X. Structural Equation Modeling: Applications Using Mplus, 2nd ed.; Standards Information Network: Tokyo, Japan, 2019.

112. Khwaja, M.G.; Zaman, U. Configuring the Evolving Role of eWOM on the Consumers Information Adoption. J. Open Innov. Technol. Mark. Complex. 2020, 6, 125. [CrossRef]

113. Zaman, U.; Florez-Perez, L.; Khwaja, M.G.; Abbasi, S.; Qureshi, M.G. Exploring the critical nexus between authoritarian leadership, project team member's silence and multi-dimensional success in a state-owned mega construction project. Int. J. Proj. Manag. 2021, 39, 873-886. [CrossRef]

114. Aktan, M.; Zaman, U.; Nawaz, S. Examining Destinations' Personality and Brand Equity through the Lens of Expats: Moderating Role of Expat's Cultural Intelligence. Asia Pac. J. Tour. Res. 2021, 26, 849-865. [CrossRef]

115. Allegretti, A.; Boffey, D.; Davis, N.; Topham, G. UK Eases COVID Travel Rules for Tourist Spots Despite Cabinet Rift. The Guardian, 24 June 2021. Available online: https:/ /www.theguardian.com/world/2021/jun/24/uk-lifts-quarantine-for-arrivalsfrom-malta-balearics-and-some-caribbean-islands (accessed on 4 November 2021).

116. Fotiadis, A. Photographs by Milos Bicanski for The Wall Street Journal. Greece Rushes to Vaccinate Islanders against COVID-19 to Save Summer Tourist Season. Wall Street Journal, 31 May 2021. Available online: https:/ /www.wsj.com/articles/greece-rushesto-vaccinate-islanders-against-COVID-19-to-save-summer-tourist-season-11622453400 (accessed on 22 October 2021).

117. Qubein, R. Cities Develop Branded COVID-19 Safety Measures to Boost Tourism. Forbes Magazine, 21 March 2021. Available online: https: / / www.forbes.com/sites/ramseyqubein/2021/03/21/cities-develop-branded-COVID-19-safety-measures-toboost-tourism $/$ ?sh $=4 \mathrm{fd} 49329247 \mathrm{~b}$ (accessed on 25 October 2021).

118. Marine-Roig, E.; Huertas, A. How Safety Affects Destination Image Projected through Online Travel Reviews. J. Destin. Mark. Manag. 2020, 18, 100469. [CrossRef]

119. Rather, R.A. Monitoring the Impacts of Tourism-Based Social Media, Risk Perception and Fear on Tourist's Attitude and Revisiting Behaviour in the Wake of COVID-19 Pandemic. Curr. Issues Tour. 2021, 24, 3275-3283. [CrossRef]

120. Sánchez-Cañizares, S.M.; Cabeza-Ramírez, L.J.; Muñoz-Fernández, G.; Fuentes-García, F.J. Impact of the Perceived Risk from COVID-19 on Intention to Travel. Curr. Issues Tour. 2021, 24, 970-984. [CrossRef]

121. Godovykh, M.; Pizam, A.; Bahja, F. Antecedents and outcomes of health risk perceptions in tourism, following the COVID-19 pandemic. Tour. Rev. 2021, 76, 737-748. [CrossRef]

122. Golets, A.; Farias, J.; Pilati, R.; Costa, H. COVID-19 pandemic and tourism: The impact of health risk perception and intolerance of uncertainty on travel intentions. Curr. Psychol. 2021, 1, 1-14. [CrossRef] [PubMed]

123. Ruan, W.; Kang, S.; Song, H. Applying Protection Motivation Theory to Understand International Tourists' Behavioural Intentions under the Threat of Air Pollution: A Case of Beijing, China. Curr. Issues Tour. 2020, 23, 2027-2041. [CrossRef] 
124. Vada, S.; Prentice, C.; Scott, N.; Hsiao, A. Positive Psychology and Tourist Well-Being: A Systematic Literature Review. Tour. Manag. Perspect. 2020, 33, 100631. [CrossRef]

125. Hosseini, S.M.; Paydar, M.M. Discount and Advertisement in Ecotourism Supply Chain. Asia Pac. J. Tour. Res. 2021, 26, 668-684. [CrossRef]

126. Rittichainuwat, B.N.; Beck, J.A.; Qu, H. Promotional Strategies and Travelerss' Satisfaction during the Asian Financial Crisis: A Best Practice Case Study of Thailand. J. Qual. Assur. Hosp. Tour. 2002, 3, 109-124. [CrossRef]

127. Chew, E.Y.T.; Jahari, S.A. Destination Image as a Mediator between Perceived Risks and Revisit Intention: A Case of Post-Disaster Japan. Tour. Manag. 2014, 40, 382-393. [CrossRef]

128. Borghese, L. One of Italy's Most Idyllic Islands Is "COVID-Free”. CNN, 11 May 2021. Available online: https://edition.cnn.com/ travel/article/capri-COVID-free-vaccination/index.html (accessed on 14 November 2021).

129. OECD. Tourism Policy Responses to the Coronavirus (COVID-19). 2021. Available online: https://www.oecd.org/coronavirus / policy-responses/tourism-policy-responses-to-the-coronavirus-COVID-19-6466aa20/ (accessed on 14 November 2021).

130. Zheng, D.; Luo, Q.; Ritchie, B.W. Afraid to Travel after COVID-19? Self-Protection, Coping and Resilience against Pandemic 'Travel Fear'. Tour. Manag. 2021, 83, 104261. [CrossRef]

131. Agrusa, J.; Kim, S.S.; Wang, K.-C. Mainland Chinese Tourists to Hawaii: Their Characteristics and Preferences. J. Travel Tour. Mark. 2011, 28, 261-278. [CrossRef]

132. Mestanza-Ramón, C.; Jiménez-Caballero, J.L. Nature Tourism on the Colombian-Ecuadorian Amazonian Border: History, Current Situation, and Challenges. Sustainability 2021, 13, 4432. [CrossRef]

133. Mestanza-Ramón, C.; Anfuso, G.; Chica-Ruiz, J.A.; Mooser, A.; Botero, C.M.; Pranzini, E. Coastal Scenic Evaluation of Continental Ecuador and Galapagos Islands: Human Impacts and Management Issues. J. Mar. Sci. Eng. 2020, 8, 468. [CrossRef]

134. Shanahan, L.; Steinhoff, A.; Bechtiger, L.; Murray, A.L.; Nivette, A.; Hepp, U.; Ribeaud, D.; Eisner, M. Emotional Distress in Young Adults during the COVID-19 Pandemic: Evidence of Risk and Resilience from a Longitudinal Cohort Study. Psychol. Med. 2020. [CrossRef]

135. Zaman, U.; Raza, S.H.; Abbasi, S.; Aktan, M.; Farías, P. Sustainable or a Butterfly Effect in Global Tourism? Nexus of Pandemic Fatigue, COVID-19-Branded Destination Safety, Travel Stimulus Incentives, and Post-Pandemic Revenge Travel. Sustainability 2021, 13, 12834. [CrossRef]

136. Zaman, U.; Aktan, M.; Gohar Qureshi, M.; Bayrakdaroglu, F.; Nawaz, S. Every storm will pass: Examining expat's host countrydestination image, cultural intelligence and renewed destination loyalty in COVID-19 tourism. Cogent Bus. Manag. 2021, 8, 1969631. [CrossRef] 